\title{
Host Response to Black Leaf Streak and Agronomic Performance of Banana Genotypes in Puerto Rico
}

\author{
Brian M. Irish and Ricardo Goenaga \\ USDA-ARS Tropical Agriculture Research Station, 2200 Pedro Albizu \\ Campos Avenue, Mayaguez, PR 00680
}

\section{Sirena Montalvo-Katz \\ Bioversity International, 2200 Pedro Albizu Campos Avenue, Mayaguez, PR 00680}

\section{Bernardo Chaves-Cordoba \\ WSU IAREC 241006 North Bunn Road, Prosser, WA 99350}

Inge Van den Bergh

Bioversity International, Belgium Office, West De Croylaan 42, 3001 Heverlee, Belgium

Additional index words. disease resistance, FLHORBAN, GCTCV, International Musa Testing Program, Musa, Pseudocercospora fijiensis, Sigatoka

\begin{abstract}
Bananas are one of the most important fruits, serving as a cash crop and staple food in many regions of the world. In Puerto Rico, bananas are an important agricultural industry, supplying all the fruit needed for local demand. Diseases significantly limit production, and the evaluation and adoption of improved genetic resistance in bananas might provide an avenue for long-term sustainable production. To this end, nine enhanced genotypes from international selection and breeding programs were introduced and evaluated for their response to black leaf streak (BLS) (Pseudocercospora fijiensis Morelet) and for their agronomic performance. Bananas were evaluated as part of a collaborative effort between the U.S. Department of Agriculture Agricultural Research Service (USDA-ARS) Tropical Agriculture Research Station (TARS) and Bioversity International's International Musa Testing Program (IMTP). Improved genotypes were compared with disease-resistant and disease-susceptible reference genotypes across two cropping cycles. Field plants were grown following commercial production practices with no BLS management. Significant differences in disease reactions were observed during both cropping cycles for test and reference genotypes. Under high disease pressure, 'FHIA-21', 'FHLORBAN 916', and 'FHLORBAN 920' test genotypes showed higher numbers of functional leaves and lower disease severity at harvest in both cycles. Short cycling times were also observed for the two FHLORBAN genotypes. Larger bunches with a high number of fruits were produced by the 'IBP 12', 'IBP 5-B', and 'IBP 5-61' selections. Several of the GCTCV test genotypes were extremely susceptible to BLS, did not perform as expected, and appeared to be offtypes. Several of the test genotypes performed well, although currently none possessed all needed traits for a commercial banana substitute. Regardless, several test genotypes have agronomic potential because they have been selected for disease resistance to other important pathogens (e.g., fusarium wilt) and therefore have become part of the permanent TARS collection. Future efforts will continue to focus on the IMTP collaboration and introduction of promising banana genotypes for evaluations.
\end{abstract}

Bananas (Musa spp.), consumed mostly for their fruit, are an important agricultural crop grown around tropical and subtropical regions of the world. They are produced as a cash crop for local and export markets and as a staple food in many developing countries.

Received for publication 8 Feb. 2019. Accepted for publication 29 July 2019.

Current address (B.M.I.): Plant Germplasm Introduction Testing and Research Unit, USDA-ARS, Prosser, WA

B.M.I. is the corresponding author. E-mail: brian. irish@usda.ars.gov. farming, culture, and daily diets. In the last Census on Agriculture for Puerto Rico, plantains ranked second in area planted $(\approx 8930$ ha) after coffee as an agricultural crop/industry (USDA-NASS, 2012). In 2015, Puerto Rican plantains were estimated to account for $\$ 72.4 \mathrm{M}$ in sales, with all other banana types accounting for another $\$ 29.0 \mathrm{M}$ in value (Instituto de Estadísticas de Puerto Rico, 2016).

Major constraints to banana production worldwide include devastating fungal, bacterial, and viral diseases, in addition to several species of plant pathogenic nematodes and insect vectors/pests. In Puerto Rico, Sigatoka leaf spot, commonly known as yellow Sigatoka, caused by Pseudocercospora musae (Zimm.) Deighton, traditionally has been a problem in plantain production areas, especially in the mountains (Gonzalez, 2009). However, the more recent incursion of Pseudocercospora fijiensis, which causes black leaf streak (BLS), commonly known as black Sigatoka, throughout the island has caused concern among producers. This has steadily led to higher production costs associated with added labor for cultural practices and increased use of fungicides, making it the most important disease in banana production on the island (Cortes et al., 2009; Irish et al., 2006). Recent fusarium wilt (FW) studies, commonly known as Panama disease, caused by Fusarium oxysporum f. sp. cubense [(E.F. Sm.) W.C. Snyder \& H.N. Hansen], showed limited genetic diversity in the pathogen population on the island, with only race 1 and race 2 being reported. Furthermore, the Cavendish-affecting tropical race 4 (TR4) was not described for the pathogen populations surveyed (Garcia et al., 2018), although global spread of this aggressive strain continues (Ordonez et al., 2015). Other important pests on the island include nematodes [Radopholus similis (Cobb) Thorne and Pratylenchus coffeae (Goodey)] and the banana weevil [Cosmopolites sordidus (Germar)] (Puerto Rico Agricultural Experiment Station, 1995). A Puerto Rican Department of Agriculture-imposed embargo on imported fruit coming to the island helps to prevent the introduction of other significant plant pathogens [e.g., Moko disease, Ralstonia solanacearum (Smith)] and shields the local markets. Ironically, fruit shortages after hurricane Maria in 2017 left no other option but to allow fresh fruit imports from Colombia, Costa Rica, and the Dominican Republic, increasing the odds of new pest ingress (Irizarry-Alvarez, 2017).

Increased competition, natural disasters (e.g., hurricane Maria), and invasive insect pests and diseases make cost-effective and sustainable banana production on the island difficult. Following the identification of $P$. fijiensis on the island in 2004, BLS has been the most important disease in banana/plantain production systems, thus requiring cultural and chemical means to effectively manage crop production. Long-term sustainable practices for managing BLS are needed, and minimizing reliance on fungicides is an 
important goal. This is especially true because fungicides can have negative effects on the environment, pose risks to the public, and add to the production costs of farmers (Aktar et al., 2009). In addition, over time, several extensively used fungicides have lost some of their efficacy due to resistance in P. fijiensis populations (Arango Isaza et al., 2016). The importation and evaluation of improved disease-resistant Musa spp. germplasm, followed by its public acceptance and commercial production, can address the many challenges that banana farmers face in Puerto Rico.

Most cultivated bananas in the world are naturally occurring diploid and triploid selections of either Musa acuminata Colla. or M. acuminata Colla. $\times$ Musa balbisiana L. hybrids; however, some synthetic tetraploid hybrids are gaining acceptance (e.g., FHIA clones in Cuba) and are being grown on smaller scales (Daniells et al., 1995; Orjeda et al., 1999). Diversity in both cultivated and wild germplasms currently exists in national and international ex situ collections (Ruas et al., 2017), with continued efforts toward germplasm exploration and acquisition to fill gaps in coverage (Sardos et al., 2018). In Puerto Rico, the USDA-ARS TARS maintains the National Plant Germplasm System's banana germplasm collection and conducts research characterizing and evaluating it. These genetic resources, kept in collections around the world, are relied on heavily by breeding and selection programs that mine them for agronomically important traits. Nevertheless, breeding bananas is problematic due to the high levels of sterility and the need for genotypes with parthenocarpic fruit that are acceptable to consumers. Several breeding programs located at international research centers aim to advance crop productivity by focusing on disease resistance and agronomic and organoleptic traits (Abadie et al., 2009; Bakry et al., 2009; Boissenet, 2002; Brown et al., 2017; Jones, 2000b; Khayat and Ortiz, 2011; Ortiz and Swennen, 2014; Salmon et al., 2005). Mutational breeding and selection of resistant/ tolerant materials are also used as a means for generating diversity and acceptable genotypes for testing (Bermudez et al., 2002; Hwang and Ko, 1987; Lee et al., 2011; Ortiz and Swennen, 2014).

The International Musa Testing Program (IMTP; http://www.promusa.org/IMTP) is a collaborative effort coordinated by Bioversity International to evaluate banana cultivars (including landraces, cultivar selections, and hybrids) in various locations around the world for their agronomic performance, host reaction to pests and diseases, and postharvest characteristics in diverse environments. The aim of the IMTP program is to identify alternative banana cultivars well-adapted to local conditions, including climatic/soil conditions, pest and disease pressure, and consumer/market requirements. From 2012 to 2017, TARS partnered with Bioversity International to field-evaluate, under the framework of the IMTP, a set of promising banana hybrids and cultivar genotypes for their host reaction to BLS and to assess their agronomic traits and production potential.

\section{Materials and Methods}

Plant material. Nine test genotypes originating from four international banana breeding/selection programs and six reference genotypes were included in the trial. The specific test genotypes (Table 1) were selected for evaluation in Puerto Rico, either for their reported resistance to BLS or for their lower susceptibility to one or more races of fusarium wilt, in addition to their good agronomic performance. The test genotypes included the following:

- two triploid (AAA) dessert-type hybrid genotypes with BLS resistance from the Center de Coopération Internationale en Recherche Agronomique pour le Développement (CIRAD) in Guadeloupe, France (Salmon et al., 2005);

- a tetraploid (AAAB) plantain-type hybrid with BLS resistance developed by the Fundación Hondureña de Investigación Agrícola (FHIA) in Honduras (Anon., 1993);

- three triploid (AAA) fusarium wilt race one-resistant 'Gros Michel' mutant selections from the Instituto de Biotecnología de las Plantas (IBP) in Cuba (Bermudez et al., 2002); and

- three triploid (AAA) Giant Cavendish Tissue Culture Variants (GCTCV) selected by the Taiwanese Banana Research Institute (TBRI) for their lower susceptibility to fusarium wilt TR4 (Hwang, 2000; Hwang and Ko, 1987; Tang and Hwang, 1994).

In addition to the test genotypes, a selection of six reference genotypes (Table 2) were included to serve as checks for disease resistance and susceptibility comparisons. These reference genotypes are wild species or cultivated genotypes that were previously identified and used as standard references for BLS screening evaluations (Carlier et al., 2002).

All plant material was received from the Bioversity International Musa Germplasm Transit Center (ITC; https://www.bioversity international.org/banana-genebank/) as virusindexed tissue culture-derived proliferating meristems. Once received, plant material continued to be propagated using standard tissue culture protocols (Vuylsteke, 1989) at TARS facilities until the desired 16 plants of each of the 15 genotypes were obtained. Plant material was then transplanted and acclimated in a greenhouse for 3 months before being established in the field. Plants were regularly watered and fertilized with water-soluble Evergreen (20-20-20 + micro elements; Plant Foods, Inc., Vero Beach, FL) and Osmocote (The Scotts Co., Marysville, OH) slow-release (19-6-12) fertilizers.
Field site and experimental design. In Aug. 2014, 15 test and reference genotypes (Tables 1 and 2) were established at TARS research farm (lat. $18^{\circ} 28^{\prime} 18.38^{\prime \prime} \mathrm{N}$, long. $67^{\circ} 3^{\prime} 4.25^{\prime \prime} \mathrm{W}$; elevation, $118 \mathrm{~m}$ ) located in Isabela, PR. The experiment was established on a well-drained Oxisol soil type (clayey, kaolinitic isohyperthermic Typic Hapludox) with a mean $\mathrm{pH}$ of $\approx 6.2$. The mean annual precipitation during the 4 years preceding experimental establishment (calendar years 2010-13) was $1596 \mathrm{~mm}$, with peaks in precipitation during the months of May and August (U.S. Department of Agriculture, 2018).

A randomized complete block design (RCBD) was used with four blocks and four replicate plants per block for each genotype. For two genotypes, not enough plants were obtained by the time the experiment was established; therefore, only three and two replicate plants per block were established for 'Pisang Klutuk Wulung' ('PKW') and 'Formosana', respectively. A border row of the BLS-susceptible 'Gran Nain' (AAA, Cavendish) was planted around all fourplant plots within a block, as well as around the whole experiment. This was done to encourage natural disease infection and to provide equal disease pressure to evaluated genotypes. Spacing between plants in a row was $1.5 \mathrm{~m}$, and between rows it was $3.0 \mathrm{~m}$. Commercial production guidelines were followed (Goenaga and Irizarry, 2000; Puerto Rico Agricultural Experiment Station, 1995), except no cultural practices or chemical applications were implemented for managing BLS. As recommended, false hands were removed as soon as apparent. However, for the 'FHIA-21' genotype, hands were intentionally reduced to four to achieve larger fruit size $(>270 \mathrm{~g})$ and more closely reflect customer/market preferences for plantain in Puerto Rico (Goenaga and Irizarry, 2006). Irrigation was provided according to production guidelines via a double drip line.

$P$. fijiensis presence. To distinguish the presence of $P$. fijiensis from other possible related fungal species in the evaluation plot, 20 isolates were recovered for testing. Pure single ascospore cultures were isolated from randomly selected senescent leaf tissue from the 'Gran Nain' border plants using a discharge technique described by Johanson and Jeger (1993). Fungal mycelium was grown in PDA broth on an orbital shaker, harvested, and lyophilized before DNA extraction. DNA was extracted using a DNeasy Plant Mini Kit (Qiagen, Valencia, CA) following the protocols of the manufacturers for fungi. DNA for each isolate was amplified using a $P$. fijiensis speciesspecific primer set (ACTR/MfactF) in combination with a positive internal control primer set (TMG3/TMG4) for the $\beta$-tubulin gene developed by Arzanlou et al. (2007). Polymerase chain reactions (PCR) also included genomic DNA from pure cultures of $P$. fijiensis, $P$. musicola, and $P$. eumusae (provided by G. Kema), as well as a negative water control to serve as a reference. All PCR were performed as described by 
Table 1. Banana (Musa spp.) test genotypes evaluated for black leaf streak (Pseudocercospora fijiensis Morelet) response and performance over two cropping cycles in Isabela, PR.

\begin{tabular}{|c|c|c|c|c|c|c|}
\hline Name & $\mathrm{ITC}^{\mathrm{z}}$ & Institute ${ }^{y}$ & Genome & Subgroup/Type & Pedigree/Derivation & Traits $^{x}$ \\
\hline FLHORBAN 920 & 1585 & CIRAD & AAA & Dessert type & $\mathrm{AA} \times \mathrm{AAA}$ & $\begin{array}{l}\text { Resistant to BLS, SLS } \\
\text { Resistant to Pc, tolerant to } \text { Rs }^{1,3,4}\end{array}$ \\
\hline IBP 12 & 1480 & IBP & AAA & Gros Michel & Mutant selection & Highly resistant to FW $\mathrm{R} 1^{6}$ \\
\hline IBP 5-B & 1479 & IBP & AAA & Gros Michel & Mutant selection & Highly resistant to FW R16 \\
\hline GCTCV-119 & 1282 & TBRI & AAA & Cavendish & Somaclonal selection & Tolerant to FW TR4 $4^{7,8}$ \\
\hline $\begin{array}{l}\text { Formosana } \\
\text { (syn. GCTCV-218) }\end{array}$ & 1597 & TBRI & AAA & Cavendish & Somaclonal selection & $\begin{array}{l}\text { Less susceptible to FW R4, } \\
\text { resistant to FW R } 1^{7}\end{array}$ \\
\hline
\end{tabular}

${ }^{\mathrm{z}}$ All material came through Bioversity International's Musa Germplasm Transit Center (ITC).

${ }^{\mathrm{y}} \mathrm{CIRAD}=$ Center de Coopération Internationale en Recherche Agronomique pour le Développent, Guadeloupe; FHIA = Fundación Hondureña de Investigación Agrícola, Honduras; IBP = Instituto Biológico de Las Plantas, Cuba; TBRI = Taiwan Banana Research Institute, Taiwan.

${ }^{\mathrm{x}}$ Reason genotypes were included in the trial: $\mathrm{BLS}=$ black leaf streak; FW = fusarium wilt; R1 = race 1; R2 = race 2; STR4 = subtropical race 4; TR4 = tropical race $4, \mathrm{Rs}=$ Radopholus similis; $\mathrm{Pc}=$ Pratylenchus coffeae .

${ }^{1}$ Salmon et al., 2005; ${ }^{2}$ Abadie et al., 2009; ${ }^{3}$ Quénéhervé et al., 2009; ${ }^{4}$ Quénéhervé et al., 2012; ${ }^{5}$ Anon., 1993; ${ }^{6}$ Bermudez et al., 2002; ${ }^{7} \mathrm{Hwang}, 2000 ;{ }^{8} \mathrm{Hwang}$ and Ko, 1987.

Table 2. Banana (Musa spp.) reference genotypes (checks) evaluated for black leaf streak (Pseudocercospora fijiensis Morelet) response and performance over two cropping cycles in Isabela, PR.

\begin{tabular}{|c|c|c|c|c|}
\hline Name & ITC\# & Genome/Species & Subgroup/Subspecies & Traits $^{y}$ \\
\hline \multirow{2}{*}{ Yangambi Km5 } & & & & Resistant to FW R1 ${ }^{2}$ \\
\hline & & & & Highly resistant to Rs, resistant to other nematodes ${ }^{3}$ \\
\hline \multirow[t]{2}{*}{ Calcutta 4} & 0249 & Musa acuminata & ssp. burmannica & Resistant to BLS ${ }^{1}$ \\
\hline & & & & Partially resistant to Rs and other nematodes \\
\hline P. Klutuk Wulung & 1587 & Musa balbisiana & & Partially resistant to $\mathrm{BLS}^{1}$ \\
\hline Pisang Ceylan & 1441 & $\mathrm{AAB}$ & Mysore & Partially resistant to $\mathrm{BLS}^{1}$ \\
\hline \multirow[t]{2}{*}{ Williams } & 0570 & AAA & Cavendish & Susceptible to BLS ${ }^{1}$ \\
\hline & & & & $\begin{array}{l}\text { Resistant to FW R1, R2, susceptible to FW TR4 }{ }^{2} \\
\text { Suscentible to all nematodes }\end{array}$ \\
\hline
\end{tabular}

${ }^{\mathrm{z}}$ All material came through Bioversity International's Musa Germplasm Transit Center (ITC).

${ }^{\mathrm{y}} \mathrm{BLS}=$ black leaf streak; $\mathrm{FW}=$ fusarium wilt; $\mathrm{R} 1=$ race $1 ; \mathrm{R} 2=$ race $2 ; \mathrm{STR} 4=$ subtropical race $4 ; \mathrm{TR} 4=$ tropical race $4, \mathrm{Rs}=$ Radopholus similis; $\mathrm{Pc}=$ Pratylenchus coffeae.

${ }^{1}$ Jones, 2000a; ${ }^{2}$ Ploetz and Pegg, 2000; ${ }^{3}$ Price, 1994.

Arzanlou et al. (2007) on a T-100 thermocycler (Bio-Rad, Hercules, CA), electrophoresed in $1.5 \%$ agarose gels, and stained with ethidium bromide. Agarose gels were visualized and photographed using the Epi Chemi II Darkroom (UVP, Upland, CA) transilluminator.

Field data collection and analyses. Reaction to BLS was assessed across genotypes by counting the number of functional leaves at shooting (i.e., flower bud emergence from pseudostem) and at harvest through two cropping cycles (i.e., mother and first ratoon). Leaves were considered functional when they were fully expanded and photosynthetically active and with less than $50 \%$ leaf lamina senescence. BLS disease severity was also assessed at shooting and at harvest for both cycles. Using Gauhl's modification of Stover's severity scale adapted from Orjeda (1998), all leaves for every plant evaluated were scored using a 0 to 6 scale $(0=$ no symptoms; $1=1 \% ; 2=2 \%$ to $5 \% ; 3=6 \%$ to $15 \% ; 4=16 \%$ to $33 \% ; 5=$ $34 \%$ to $50 \%$; and $6=>51 \%$ of the leaf area affected). The disease severity index was calculated using the following formula (Craenen, 1998):

$$
\begin{array}{r}
\text { Disease severity index }(D S I) \\
=[(\Sigma n b) /(N-1) T] \times 100,
\end{array}
$$

where $n=$ number of leaves with a given rating, $b=$ rating, $N=$ seven total ratings/grades of the scale, and $T=$ total number of leaves scored.

In addition to assessing the direct effects of BLS, the agronomic performance of the genotypes under severe disease pressure was also measured. During both cropping cycles, days to shooting and to harvest as well as plant height and circumference were measured. Because there was no way to standardize harvesting based on specific dates because all genotypes evaluated matured at different rates, all bunches were harvested when physiologically mature and when it was evident that fruit on bunches began to ripen. To determine cycling times, the shooting date and harvest were recorded and days to harvest for each cycle were calculated based on the original planting date. Plant height was measured from the base of the pseudostem to the last/highest intersecting leaf petioles on the shooting day, with the circumference measured at $1 \mathrm{~m}$ from the pseudostem base. Bunch metrics, including net weight (total bunch weight - rachis weight), number of hands and fruit, along with weight, length, and width for third hand fruit were also determined at the time of harvest.

Statistical analyses of the data were performed using SAS version 9.4 statistical software (SAS Institute, Cary, NC). A weighted analysis of variance was performed using the GLM procedure to fix the unbalance due to missing values and to calculate the estimates per plant. Genotypes and cropping cycles were fixed factors, and blocks were treated as random factors. After significant differences were shown, means were separated using the Tukey-Kramer pairwise comparison.

\section{Results}

Disease symptoms were first noted $\approx 6$ months after field establishment for 'Gran Nain' border plants and other susceptible 
genotypes, with disease pressure continually high throughout the remainder of the evaluation period. Resistant reference genotypes scored high for functional leaves and low for DSI compared with susceptible reference genotypes that performed poorly, as expected. Generally, test genotypes with common genetic backgrounds (e.g., GCTCV Cavendish variants and IBP - 'Gros Michel' selections) or that originated from a specific breeding program (FLHORBAN genotypes) performed similarly when compared with each other. Statistical analyses showed significant interactions between genotypes across cropping cycles; therefore, data are presented separately for the mother and ratoon crops (Tables 3-6). Regrettably, no plants for 'GCTCV-119' or for 'Formosana' survived to the ratoon crop; hence, their data are lacking.

P. fijiensis presence. P. fijiensis was confirmed at the TARS research farm in Isabela using molecular diagnostic speciesspecific DNA primers (Fig. 1). DNA was extracted and amplified from the 20 random single ascospore isolates collected from the field site. All 20 DNA samples produced a diagnostic amplicon $(\approx 500 \mathrm{bp})$ for $P$. fijiensis in addition to the internal $\beta$-tubulin fragment $(\approx 300$ bp) (Fig. 1). The diagnostic and internal control amplicons were also amplified in the positive $P$. fijiensis control, but only the $\beta$-tubulin fragment was visualized for other Pseudocercospora species. No PCR amplicons were evident for the negative water control.

Disease response. Significant differences were found for the number of functional leaves and DSI at shooting and at harvest in both the mother crop and the ratoon crop (Table 3, Supplemental Table 1). In the mother crop, 'PKW', 'Calcutta 4', 'FHIA21', and 'Pisang Ceylan' had means greater than 14 functional leaves at shooting, and the means were not significantly different from each other. The lowest number of functional leaves at shooting in the mother crop was found for 'Yangambi Km5' and 'Gros
Michel', with 10.0 and 10.1 leaves, respectively. At harvest, the number of functional leaves for the mother crop had decreased considerably for all genotypes. 'PKW' had the most functional leaves (11.3), with ' $\mathrm{Cal}$ cutta 4' and 'Formosana' only having means of 3.1 and 0.7 leaves per plant at harvest, respectively.

DSI for the mother cycle was generally low at shooting, but significant differences were observed among tested genotypes (Table 3). The partially resistant 'PKW' and highly resistant 'Calcutta 4', as well as the test genotypes 'FHIA-21', 'FLHORBAN 916', and 'FLHORBAN 920', had the lowest DSI values (range, 0.6-1.6). The highest DSI value at shooting (34.5) was observed for the susceptible reference genotype 'Williams'. At harvest, DSI values of the mother crop increased for all genotypes, except 'Calcutta 4', and were significantly different as well. The lowest DSI value was for 'Calcutta 4' $(0.0)$, and the highest was observed for 'Formosana' (98.7).

For most genotypes of the first ratoon crop, the mean number of functional leaves was lower and the mean DSI value was higher when compared with the mother crop (Table 3). A notable exception was the two FLHORBAN genotypes and 'Calcutta 4', which had a higher number of functional leaves at harvest and lower DSI values at shooting. Two highly susceptible genotypes (i.e., 'GCTCV-119' and 'Formosana') did not survive to the ratoon crop. In the second cycle, 'PKW' continued to have as high of number of functional leaves at shooting and at harvest (15.3 and 8.8, respectively) as it had in the mother crop, whereas 'IBP 12' and 'GCTCV-015' both had the lowest number (7.7). At harvest, the number of leaves ranged from 10.8 for 'Calcutta 4' to an approximate mean of one single leaf for 'Williams' and 'GCTCV 105'. 'Calcutta 4' showed no symptoms and had DSI values of 0 at shooting and 1.1 at harvest compared with 32.2 and 76.9 , respectively, for 'Williams. 'FLHORBAN 916', 'FLHORBAN 920' and 'FHIA-21' also had very low DSI values at shooting $(0.8,1.0$, and 2.8 , respectively), whereas 'GCTCV105 ' had the highest DSI at harvest (78.1).

Across the two production cycles, the reference genotypes reacted as expected, with a high number of functional leaves and low DSI values for resistant checks and a low number of functional leaves and mediumhigh DSI values for the susceptible checks (Table 3). A notable exception was 'Yangambi Km5', which is reported as highly resistant to BLS but was found to have a low number of functional leaves and high DSI values in this trial. Except for 'FLHORBAN 920' at the harvest stage in the first ratoon, test genotypes 'FHIA 21', 'FLHORBAN 916', and 'FLHORBAN 920' were not significantly different from the resistant checks in their DSI ratings. 'Formosana', 'GCTCV119', and 'GCTCV-105' showed similar DSI values as the susceptible checks. The three IBP genotypes showed an intermediate host reaction to BLS. A direct comparison could be made between the IBP selections and the 'Gros Michel' reference genotype because they originate from the same subgroup and genetic background. The IBP selections generally appeared to rate lower for DSI, especially at shooting in the first ratoon, where they were significantly different from 'Gros Michel'. A similar comparison could be made for the GCTCV genotypes and the 'Williams' reference genotype. 'GCTCV119' and 'GCTCV-105' (which made it through two cycles) appeared to be marginally better performing than 'Williams'. However, the 'Formosana' genotype was extremely susceptible when compared with 'Williams' in the mother cycle at harvest.

Agronomic performance. Significant differences were found among genotypes for mean days to shooting and harvest in both cropping cycles (Table 4, Supplemental Table 2). The shortest cycling times were found for 'FLHORBAN 916', 'FLHORBAN 920', and 'Calcutta 4'. 'FLHORBAN 916' took a mean of $169 \mathrm{~d}$ to shoot and completed its first cycle in just over 9 months $(273 \mathrm{~d})$. Two full

Table 3. Black leaf streak (Pseudocercospora fijiensis Morelet) disease response of banana (Musa spp.) test and reference genotypes (bold) evaluated over two cropping cycles in Isabela, PR.

\begin{tabular}{|c|c|c|c|c|c|c|c|c|}
\hline \multirow{2}{*}{ Accession } & \multicolumn{4}{|c|}{ First cycle (mother) } & \multicolumn{4}{|c|}{ Second cycle (first ratoon) } \\
\hline & \multicolumn{2}{|c|}{ No. of functional leaves } & \multicolumn{2}{|c|}{$\mathrm{DSI}^{\mathrm{z}}$} & \multicolumn{2}{|c|}{ No. of functional leaves } & \multicolumn{2}{|c|}{ DSI } \\
\hline FLHORBAN 916 & $11.1 \mathrm{~d}-\mathrm{f}^{\mathrm{y}}$ & $4.0 \mathrm{de}$ & $1.2 \mathrm{~d}$ & $20.2 \mathrm{~d}-\mathrm{g}$ & $9.9 \mathrm{~cd}$ & $5.1 \mathrm{c}-\mathrm{e}$ & $0.8 \mathrm{e}$ & $12.7 \mathrm{~d}-\mathrm{f}$ \\
\hline FHIA-21 & $14.7 \mathrm{ab}$ & $8.0 \mathrm{~b}$ & $0.8 \mathrm{~d}$ & $1.8 \mathrm{fg}$ & $10.4 \mathrm{~b}-\mathrm{d}$ & $5.3 \mathrm{c}-\mathrm{e}$ & $2.8 \mathrm{e}$ & $6.9 \mathrm{ef}$ \\
\hline IBP 12 & $11.4 \mathrm{~d}-\mathrm{f}$ & $8.1 \mathrm{~b}$ & $9.2 \mathrm{~cd}$ & $16.5 \mathrm{~d}-\mathrm{g}$ & $7.7 \mathrm{~d}$ & $4.1 \mathrm{de}$ & $19.9 \mathrm{~b}$ & $40.3 \mathrm{a}-\mathrm{e}$ \\
\hline IBP 5-B & $11.4 \mathrm{~d}-\mathrm{f}$ & $8.1 \mathrm{~b}$ & $7.8 \mathrm{~cd}$ & $16.7 \mathrm{~d}-\mathrm{g}$ & $8.0 \mathrm{~d}$ & $2.7 \mathrm{~d}-\mathrm{f}$ & $16.5 \mathrm{~b}$ & $62.1 \mathrm{ab}$ \\
\hline IBP 5-61 & $10.5 \mathrm{~d}-\mathrm{f}$ & $7.8 \mathrm{bc}$ & $7.0 \mathrm{~cd}$ & $16.8 \mathrm{~d}-\mathrm{g}$ & $8.4 \mathrm{~d}$ & $3.2 \mathrm{~d}-\mathrm{f}$ & $14.5 \mathrm{~b}-\mathrm{d}$ & $51.6 \mathrm{a}-\mathrm{c}$ \\
\hline Formosana & $12.0 \mathrm{c}-\mathrm{f}$ & $0.7 \mathrm{f}$ & $18.8 \mathrm{~b}$ & $98.7 \mathrm{a}$ & - & - & - & - \\
\hline Yangambi Km5 & $10.0 \mathrm{f}$ & $3.5 \mathrm{de}$ & $6.7 \mathrm{~cd}$ & $47.1 \mathrm{bc}$ & $8.4 \mathrm{~d}$ & 2.4 ef & 23.9 ab & 56.0 ab \\
\hline Calcutta 4 & 14.9 ab & 3.1 ef & $1.1 \mathrm{~d}$ & $0.0 \mathrm{~g}$ & 11.8 bc & 10.8 a & $0.0 \mathrm{e}$ & $1.1 \mathrm{f}$ \\
\hline P. Klutuk Wulung & 15.4 a & $11.3 \mathrm{a}$ & $0.6 \mathrm{~d}$ & $12.2 \mathrm{e}-\mathrm{g}$ & $15.3 \mathrm{a}$ & 8.8 ab & $5.2 \mathrm{de}$ & $27.3 \mathrm{~b}-\mathrm{f}$ \\
\hline Pisang Ceylan & $14.1 \mathrm{a}-\mathrm{c}$ & $7.9 \mathrm{bc}$ & $6.1 \mathrm{~cd}$ & $14.8 \mathrm{~d}-\mathrm{g}$ & 12.8 ab & $7.6 \mathrm{bc}$ & $6.2 \mathrm{c}-\mathrm{e}$ & 10.5 ef \\
\hline Gros Michel & $10.1 \mathrm{f}$ & $5.9 \mathrm{~b}-\mathrm{d}$ & $8.7 \mathrm{~cd}$ & $26.2 \mathrm{c}-\mathrm{f}$ & $8.6 \mathrm{~d}$ & $2.7 \mathrm{~d}-\mathrm{f}$ & $5.8 \mathrm{c}-\mathrm{e}$ & 50.1 a-d \\
\hline Williams & $12.9 \mathrm{~b}-\mathrm{d}$ & $3.8 \mathrm{de}$ & $34.5 \mathrm{a}$ & $62.3 \mathrm{~b}$ & $8.4 \mathrm{~d}$ & $1.0 \mathrm{f}$ & $32.2 \mathrm{a}$ & $76.9 \mathrm{a}$ \\
\hline
\end{tabular}

${ }^{\mathrm{z}}$ DSI = disease severity index from formula developed by Craenen (1998) based on the 0-6 rating scale of Orjeda (1998).

${ }^{\mathrm{y}}$ Means followed by the same letter within a column are not significantly different according to the least significant difference test at $P=0.05$. 
cycles for this genotype were completed in $468 \mathrm{~d}$ (369 d to shoot). 'FLHORBAN 920' was also quick to complete its first cycle and was harvested for the first time at $296 \mathrm{~d}$ (178 d to shoot), and it took $474 \mathrm{~d}$ ( $371 \mathrm{~d}$ to shoot) to be harvested a second time. The 'Calcutta 4' reference genotype is an unimproved diploid $M$. acuminata subsp. burmannica accession that has been used extensively in breeding for BLS resistance and is known to have fast cycling times between crops. In contrast, two of the reference genotypes took more than 2 years to cycle a second time, with 'PKW' and 'Yangambi km5' needing 736 and 792 d, respectively. Except for the FLHORBAN genotypes, cycling times for other test and cultivated genotypes were comparable, and most were not significantly different from each other for either the mother crop or the ratoon crop.

Pseudostem height and circumference varied noticeably between the evaluated genotypes in both cycles (Table 4). A clear association existed between the height of the pseudostem and circumference: increasing pseudostem height usually generated larger circumferences. In all cases, height was greater for genotypes in the ratoon crop; in all but two genotypes ('FLHORBAN 920' and 'Calcutta 4'), the circumference increased as well. 'Calcutta 4' was the shortest genotype, with pseudostem heights of $2.17 \mathrm{~m}$ and $2.33 \mathrm{~m}$ in the mother crop and ratoon crop, respectively. It also showed the smallest circumference in both cycles $(43.0 \mathrm{~cm}$ and $34.9 \mathrm{~cm})$. The two FLHORBAN genotypes, with their short cycling times, were also comparatively short and had pseudostems with smaller circumferences, but these did not differ significantly from 'GCTCV-105' and 'Williams'. 'PKW' was extremely tall and sturdy in both cropping cycles, with plant heights of $4.65 \mathrm{~m}$ and $4.74 \mathrm{~m}$ and pseudostem circumferences of $73.2 \mathrm{~cm}$ and $79.2 \mathrm{~cm}$, in the mother crop and ratoon crop cycle, respectively. The 'GCTCV 105' genotype was very similar to 'Williams' regarding height and circumference. An equivalent observation could be made for the IBP genotypes when compared with the 'Gros Michel' reference.

Yield. Test and reference genotypes varied significantly for yield, and this was partly influenced by cultural practices (Table 6, Supplemental Tables 3 and 4). Because of the deliberate reduction of the number of hands in 'FHIA-21', a lower number of fruits with increased third hand metrics (heavy, long, and wide fruit) was observed, reflecting the expected performance as a plantain (Fig. 2). Relatively small bunches with few hands and fruit were produced by the 'FLHORBAN 916' test genotype, especially in the mother crop (Table 5). An adjustment in the precise identification of the false hand (false hand removal was a standard cultural practice) in the second cycle for 'FHLORBAN 916' resulted in an increased number of hands and fruits per bunch. Despite having intermediate to high DSI scores, especially in the second cycle, IBP selections appeared to outperform the 'Gros Michel' reference genotype (Fig. 3) and other test genotypes with larger bunches and third hands, with a higher mean number of hands and fruit in both cycles. In addition, during both cycles, the 'GCTCV105 ' test genotype also performed quite well for yield parameters (e.g., bunch weight, number of hands and fruit) when compared with 'Williams'.

\section{Discussion}

To identify disease-resistant, productive banana germplasm for the island of Puerto

Table 4. Agronomic data for banana (Musa spp.) test and reference genotypes (bold) evaluated for black leaf streak (Pseudocercospora fijiensis Morelet) response and performance over two cropping cycles in Isabela, PR.

\begin{tabular}{|c|c|c|c|c|c|c|c|c|}
\hline \multirow[b]{3}{*}{ Accession } & \multicolumn{4}{|c|}{ First cycle (mother) } & \multicolumn{4}{|c|}{ Second cycle (first ratoon) } \\
\hline & \multicolumn{2}{|c|}{ Days to } & \multicolumn{2}{|c|}{ Plant } & \multicolumn{2}{|c|}{ Days to } & \multicolumn{2}{|c|}{ Plant } \\
\hline & Shoot & Harvest & $\mathrm{Ht}(\mathrm{m})$ & Circ. $(\mathrm{cm})$ & Shoot & Harvest & Ht (m) & Circ. $(\mathrm{cm})$ \\
\hline FLHORBAN 916 & $169 \mathrm{f}^{\mathrm{z}}$ & $273 \mathrm{f}$ & $2.63 \mathrm{fg}$ & $49.9 \mathrm{~h}$ & $369 \mathrm{de}$ & $468 \mathrm{~d}$ & $2.95 \mathrm{~d}-\mathrm{f}$ & $50.2 \mathrm{ef}$ \\
\hline FLHORBAN 920 & $178 \mathrm{f}$ & $296 \mathrm{~d}-\mathrm{f}$ & $2.67 \mathrm{fg}$ & $43.3 \mathrm{i}$ & $371 \mathrm{de}$ & $474 \mathrm{~d}$ & $3.08 \mathrm{de}$ & $42.1 \mathrm{fg}$ \\
\hline FHIA-21 & $291 \mathrm{~b}-\mathrm{d}$ & 393 bc & $3.19 \mathrm{de}$ & $58.5 \mathrm{e}-\mathrm{g}$ & $603 \mathrm{ab}$ & $662 \mathrm{bc}$ & $3.53 \mathrm{~cd}$ & $65.6 \mathrm{~cd}$ \\
\hline IBP 12 & $258 \mathrm{de}$ & $350 \mathrm{~b}-\mathrm{e}$ & $3.72 \mathrm{bc}$ & $68.3 \mathrm{ab}$ & $584 \mathrm{bc}$ & $664 \mathrm{bc}$ & $4.07 \mathrm{bc}$ & $76.6 \mathrm{a}-\mathrm{c}$ \\
\hline IBP 5-B & $268 \mathrm{c}-\mathrm{e}$ & $361 \mathrm{~b}-\mathrm{d}$ & $3.71 \mathrm{bc}$ & $68.1 \mathrm{ab}$ & $620 \mathrm{ab}$ & $696 \mathrm{a}-\mathrm{c}$ & $4.35 \mathrm{ab}$ & $79.9 \mathrm{ab}$ \\
\hline IBP 5-61 & $261 \mathrm{c}-\mathrm{e}$ & $356 \mathrm{~b}-\mathrm{e}$ & $3.69 \mathrm{bc}$ & $67.6 \mathrm{a}-\mathrm{c}$ & $610 \mathrm{ab}$ & $680 \mathrm{bc}$ & $4.27 \mathrm{ab}$ & $77.4 \mathrm{ab}$ \\
\hline GCTCV-105 & $255 \mathrm{de}$ & $337 \mathrm{c}-\mathrm{e}$ & $2.62 \mathrm{fg}$ & $55.5 \mathrm{f}-\mathrm{h}$ & $584 \mathrm{bc}$ & $667 \mathrm{bc}$ & $2.77 \mathrm{ef}$ & $57.7 \mathrm{de}$ \\
\hline GCTCV-119 & $330 \mathrm{a}-\mathrm{c}$ & $412 \mathrm{~b}$ & $3.07 \mathrm{de}$ & $59.7 \mathrm{~d}-\mathrm{g}$ & - & - & - & - \\
\hline Formosana & $301 \mathrm{~b}-\mathrm{d}$ & $399 \mathrm{bc}$ & $2.83 \mathrm{ef}$ & $61.1 \mathrm{~d}-\mathrm{f}$ & - & - & - & - \\
\hline Yangambi Km5 & 397 a & 516 a & 3.22 de & $62.0 \mathrm{c}-\mathrm{e}$ & 701 a & 792 a & $4.42 \mathrm{ab}$ & 86.9 a \\
\hline Calcutta 4 & $157 \mathrm{f}$ & 289 e-f & $2.17 \mathrm{~h}$ & $43.0 \mathrm{i}$ & 330 e & $409 d$ & $2.33 \mathrm{f}$ & $34.9 \mathrm{~g}$ \\
\hline P. Klutuk Wulung & $351 \mathrm{ab}$ & 502 a & $4.65 \mathrm{a}$ & $73.2 \mathrm{a}$ & $640 \mathrm{ab}$ & 736 ab & $4.74 \mathrm{a}$ & $79.2 \mathrm{ab}$ \\
\hline Pisang Ceylan & 259 de & 390 bc & $3.33 \mathrm{~cd}$ & 59.0 e-g & $472 \mathrm{~cd}$ & 599 c & $3.98 \mathrm{bc}$ & 71.4 bc \\
\hline Gros Michel & 259 de & 356 b-e & $3.79 \mathrm{~b}$ & $64.9 \mathrm{~b}-\mathrm{d}$ & $604 \mathrm{ab}$ & $682 \mathrm{bc}$ & $4.20 \mathrm{ab}$ & 73.9 bc \\
\hline Williams & 203 ef & 309 d-f & $2.31 \mathrm{gh}$ & $55.1 \mathrm{gh}$ & $475 \mathrm{~cd}$ & 598 c & 2.52 ef & 56.9 de \\
\hline
\end{tabular}

${ }^{\mathrm{z}}$ Means followed by the same letter within a column are not significantly different according to the least significant difference test at $P=0.05$.

Table 5. Yield data for the first cycle (mother) banana (Musa spp.) test and reference genotypes (bold) evaluated for black leaf streak (Pseudocercospora fijiensis Morelet) response and performance in Isabela, PR

\begin{tabular}{|c|c|c|c|c|c|c|}
\hline \multirow[b]{2}{*}{ Accession } & \multicolumn{3}{|c|}{ Bunch } & \multicolumn{3}{|c|}{ Third hand } \\
\hline & Wt $(\mathrm{kg})$ & \# Hands & \# Fruits & $\overline{\mathrm{Wt}}(\mathrm{kg})$ & Length $(\mathrm{cm})$ & Width $(\mathrm{cm})$ \\
\hline FLHORBAN 920 & $14.4 \mathrm{e}-\mathrm{g}$ & $8.3 \mathrm{ef}$ & $131.5 \mathrm{c}-\mathrm{e}$ & $3.07 \mathrm{~b}-\mathrm{e}$ & $16.1 \mathrm{e}-\mathrm{g}$ & $3.97 \mathrm{~b}$ \\
\hline FHIA-21 & $21.9 \mathrm{c}-\mathrm{e}$ & $4.0 \mathrm{~g}$ & $60.9 \mathrm{f}$ & $5.18 \mathrm{a}$ & $27.9 \mathrm{a}$ & $4.79 \mathrm{a}$ \\
\hline IBP 5-B & $30.7 \mathrm{ab}$ & $10.2 \mathrm{~b}-\mathrm{d}$ & $163.3 \mathrm{~b}-\mathrm{d}$ & $3.68 \mathrm{~b}$ & $21.0 \mathrm{~b}-\mathrm{d}$ & $3.82 \mathrm{bc}$ \\
\hline IBP 5-61 & $32.6 \mathrm{ab}$ & $10.1 \mathrm{~b}-\mathrm{d}$ & $168.3 \mathrm{bc}$ & $4.07 \mathrm{ab}$ & $21.5 \mathrm{bc}$ & $3.91 \mathrm{bc}$ \\
\hline GCTCV-105 & $28.7 \mathrm{a}-\mathrm{c}$ & $10.7 \mathrm{a}-\mathrm{c}$ & $220.6 \mathrm{a}$ & $3.49 \mathrm{bc}$ & $17.7 \mathrm{c}-\mathrm{f}$ & $3.31 \mathrm{~cd}$ \\
\hline Yangambi Km5 & $7.0 \mathrm{gh}$ & $6.8 \mathrm{f}$ & $158.0 \mathrm{~b}-\mathrm{d}$ & $1.13 \mathrm{fg}$ & $8.6 \mathrm{~h}$ & $2.75 \mathrm{de}$ \\
\hline Calcutta 4 & $1.5 \mathrm{~h}$ & $6.8 \mathrm{f}$ & $131.5 \mathrm{c}-\mathrm{e}$ & $0.30 \mathrm{~g}$ & $7.4 \mathrm{~h}$ & $1.43 \mathrm{f}$ \\
\hline P. Klutuk Wulung & $14.2 \mathrm{e}-\mathrm{g}$ & $12.1 \mathrm{a}$ & $176.6 \mathrm{~b}$ & $0.95 \mathrm{fg}$ & $13.1 \mathrm{~g}$ & $2.60 \mathrm{e}$ \\
\hline Pisang Ceylan & $22.3 \mathrm{c}-\mathrm{d}$ & $11.0 \mathrm{ab}$ & 190.6 ab & $2.14 \mathrm{~d}-\mathrm{f}$ & 14.7 gf & 3.75 bc \\
\hline Gros Michel & 25.9 a-c & 9.0 d-e & $151.3 \mathrm{~b}-\mathrm{e}$ & $3.41 \mathrm{~b}-\mathrm{d}$ & $20.4 \mathrm{~b}-\mathrm{d}$ & $3.84 \mathrm{bc}$ \\
\hline Williams & 25.7 bc & $8.9 \mathrm{~d}-\mathrm{e}$ & 163.9 bc & $3.36 \mathrm{~b}-\mathrm{d}$ & $21.7 \mathrm{~b}$ & $3.65 \mathrm{bc}$ \\
\hline
\end{tabular}

${ }^{\mathrm{z}}$ Means followed by the same letter within a column are not significantly different according to the least significant difference test at $P=0.05$. 
Table 6. Yield data for the second cycle (first ratoon) banana (Musa spp.) test and reference genotypes (bold) evaluated for black leaf streak (Pseudocercospora fijiensis Morelet) response and performance in Isabela, PR.

\begin{tabular}{|c|c|c|c|c|c|c|}
\hline \multirow[b]{2}{*}{ Accession } & \multicolumn{3}{|c|}{ Bunch } & \multicolumn{3}{|c|}{ Third hand } \\
\hline & $\overline{\mathrm{Wt}(\mathrm{kg})}$ & Hands & Fruit & $\overline{\mathrm{Wt}}(\mathrm{kg})$ & Length $(\mathrm{cm})$ & Width $(\mathrm{cm})$ \\
\hline FLHORBAN 920 & $13.1 \mathrm{~cd}$ & $9.2 \mathrm{bc}$ & $140.4 \mathrm{c}-\mathrm{f}$ & $1.50 \mathrm{de}$ & 13.7 ef & $3.37 \mathrm{a}-\mathrm{c}$ \\
\hline FHIA-21 & $18.8 \mathrm{a}-\mathrm{c}$ & $4.1 \mathrm{~d}$ & $63.4 \mathrm{~g}$ & $4.38 \mathrm{a}$ & $26.8 \mathrm{a}$ & $3.96 \mathrm{a}$ \\
\hline IBP 5-B & $21.5 \mathrm{ab}$ & $9.0 \mathrm{bc}$ & $136.1 \mathrm{c}-\mathrm{f}$ & $2.89 \mathrm{~b}$ & $20.2 \mathrm{~b}$ & $3.38 \mathrm{a}-\mathrm{c}$ \\
\hline IBP 5-61 & $20.7 \mathrm{ab}$ & $8.8 \mathrm{bc}$ & $136.1 \mathrm{c}-\mathrm{f}$ & $2.85 \mathrm{~b}$ & $20.3 \mathrm{~b}$ & $3.35 \mathrm{bc}$ \\
\hline GCTCV-105 & $15.1 \mathrm{bc}$ & $9.6 \mathrm{a}$ & $160.6 \mathrm{~cd}$ & $1.92 \mathrm{~cd}$ & $15.9 \mathrm{de}$ & $2.86 \mathrm{~cd}$ \\
\hline Yangambi Km5 & $7.5 \mathrm{de}$ & 8.4 bc & $201.3 \mathrm{~b}$ & 0.96 ef & $8.2 \mathrm{~g}$ & $2.56 \mathrm{de}$ \\
\hline Calcutta 4 & 0.7 e & $7.5 \mathrm{c}$ & $130.8 \mathrm{~d}-\mathrm{f}$ & $0.11 \mathrm{~g}$ & $5.5 \mathrm{~g}$ & $1.03 \mathrm{f}$ \\
\hline P. Klutuk Wulung & $6.4 \mathrm{de}$ & $11.7 \mathrm{a}$ & $167.3 \mathrm{bc}$ & $0.42 \mathrm{fg}$ & $11.5 \mathrm{f}$ & $1.96 \mathrm{e}$ \\
\hline Pisang Ceylan & $23.7 \mathrm{a}$ & $13.1 \mathrm{a}$ & 256.4 a & $2.18 \mathrm{c}-\mathrm{d}$ & 14.1 ef & $3.50 \mathrm{ab}$ \\
\hline Gros Michel & 19.1 a-c & $7.7 \mathrm{c}$ & $114.9 \mathrm{f}$ & $2.82 \mathrm{~b}$ & $20.2 \mathrm{~b}$ & $3.48 \mathrm{ab}$ \\
\hline Williams & 14.9 bc & 8.9 bc & 159.1 c-e & $2.25 \mathrm{~b}-\mathrm{d}$ & 17.7 b-d & 2.94 b-d \\
\hline
\end{tabular}

${ }^{{ }^{z}}$ Means followed by the same letter within a column are not significantly different according to the least significant difference test at $P=0.05$.

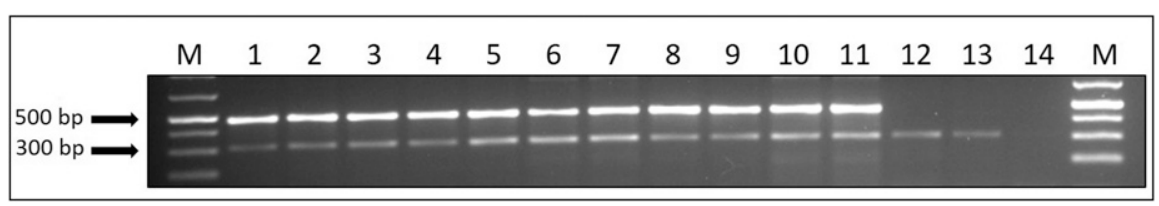

Fig. 1. Confirmation of (Pseudocercospora fijiensis Morelet) presence by use of species-specific primer sets (ACTR/MfactF) in combination with a positive internal $\beta$-tubulin fragment control (TMG3/ TMG4) developed by Arzanlou et al. (2007). Lanes 1-10 correspond to unknown Pseudocercospora spp. DNA samples from single ascospore isolates recovered from banana (Musa spp.) plants on the USDA-ARS TARS research farm in Isabela, PR. Lanes 11, 12, and 13 are positive controls for genomic DNA from pure cultures of $P$. fijiensis, $P$. musicola, and $P$. eumusae. Lane $14=$ negative control (water and no template DNA); $M=$ DNA marker (100-bp Ladder).

Rico and the region, TARS partnered with Bioversity International and its International Musa Testing Program to introduce and evaluate improved banana genotypes from international breeding and selection programs (Tables 1 and 2). A total of nine introduced test genotypes were compared with six selected reference genotypes for their BLS reaction and agronomic performance over two cropping cycles. The test genotypes were selected for evaluation because they had been described as having improved disease and/or agronomics traits, and because they were available through the IMTP. The reference genotypes were chosen to represent cultivated and wild germplasm with good agronomic performance and/or superior disease resistance for comparisons.

BLS disease pressure was high over the evaluation period; susceptible and several of the test genotypes showed low numbers of functional leaves and high disease indices. However, the numbers of functional leaves and DSI at shooting, especially for the mother crop, were not the best indicators of disease reaction and resistance, presumably because not enough time had elapsed from planting to bunch shooting for disease pressure to have increased. Therefore, differences in functional leaves and DSI were not as evident as they would be later in the evaluation. A high number of functional leaves and low disease severity are desirable between shooting and bunch harvest because this is a period when no new leaves emerge from the plant's pseudostem, and fruit needs to fill for marketability (Jimenez et al., 2007). Despite the low disease incidence at flowering, one of the test genotypes, 'Formosana' ('GCTCV-218') was extremely susceptible to BLS and showed the lowest number of functional leaves and the highest DSI at harvest in the mother crop. GCTCV genotypes are Cavendish-derived tissue culture variants that have been selected for FW TR4 resistance; therefore, it is not surprising that they are not more resistant to BLS than other Cavendish varieties (Hwang and Ko, 1990, 2004; Molina et al., 2011). However, the fact that the 'Formosana' genotype was extremely susceptible with odd 'upright' leaf orientation could be an indication of an offtype that possibly arose during the tissue culture multiplication (propagation) process.

In contrast, and as expected, resistant reference genotypes 'Calcutta 4', 'PKW', and 'Pisang Ceylan' showed higher number of functional leaves and lower DSI at harvest in the ratoon crop when disease pressure would have been the highest. At least three of the test genotypes also performed well in disease reaction evaluations. The two FLHORBAN genotypes, which were selected for BLS disease resistance in the Caribbean (Abadie et al., 2009), performed well when evaluated for their disease reaction, with a relatively high number of functional leaves and lower DSI. A unique observation was made in the case of these two genotypes. The number of functional leaves increased and DSI decreased in the ratoon crop. Although the ratings were not substantially different between cycles, it would have been expected that plants exposed to disease pressure for longer would have been more susceptible. It is possible that the disease reaction in the FLHORBAN genotypes also might have been influenced by environmental conditions. These two genotypes completed their cycles quickly when compared with other genotypes, and their shooting-toharvest interval might have coincided with a dryer time of the year. It is possible these genotypes 'escaped' higher disease pressure, because increased ascospore production for $P$. fijiensis has previously been associated with high relative humidity and rainfall (Gauhl, 1994; Meredith et al., 1973).

In a similar study in Puerto Rico, Irish et al. (2013) identified several genotypes originating from the FHIA breeding program as having excellent disease resistance to BLS as well as good agronomic performance. In the current evaluation, 'FHIA-21' was the only genotype included from this program; as found in other reports of studies performed in Puerto Rico (Gonzalez-Velez, 2014; Irish et al., 2013), its disease resistance was high when compared with the other test and reference genotypes. Banana streak virus symptoms had been noticed in other 'FHIA21 ' plantings at the research station (B. Irish and R. Goenaga, personal observation), and this has been a problem reported in tissue culture-derived FHIA materials (Dallot et al., 2001; Gonzalez-Velez, 2014); however, it was not evident in any of the 16-replicate plants in this evaluation.

When comparing agronomic performance, two of the test genotypes ('FLHORBAN 916' and 'FLHORBAN 920') had short cycling times, with only the diploid ' $\mathrm{Cal}$ cutta 4' reference genotype being harvested sooner. It is probable that the leaf emergence rate for these genotypes was faster than that for others, thus influencing the shorter shooting/harvest times. Regardless of the BLS resistance and short cycling times, the 


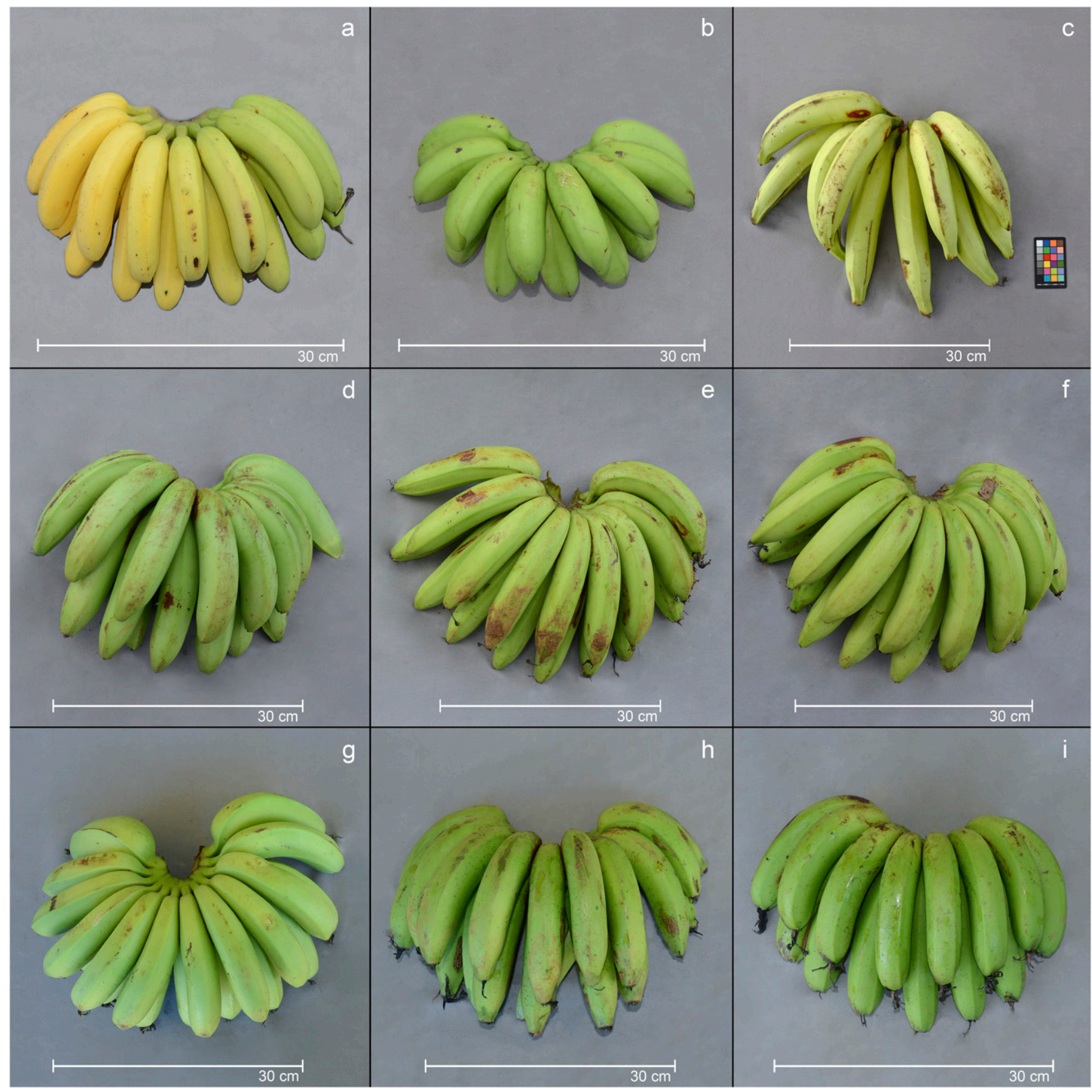

Fig. 2. Representative third hands and fruit for banana (Musa spp.) test genotypes evaluated for black leaf streak (Pseudocercospora fijiensis Morelet) response and performance over two cropping cycles in Isabela, PR: (a) 'FLHORBAN 916'; (b) 'FLHORBAN 920'; (c) 'FHIA-21'; (d) 'IBP 12'; (e) 'IBP 5-B'; (f) 'IBP 5-61'; (g) 'GCTCV-105' (h) 'GCTCV-119'; and (i) 'Formosana'.

FLHORBAN genotypes produced small bunches and their pseudostems required staking. Therefore, the two FHLORBAN genotypes were outperformed in their agronomic traits (e.g., bunch size, number of hands and fruit) by the more BSL-susceptible Cavendish and Gros Michel test references. Our observations parallel those expressed in the ProMusa pages for these two genotypes (Van den Bergh and Vézina, 2018; Van den Bergh et al., 2018). The short cycling times observed for the FHLORBAN genotypes might lead to increased productivity over time, compensating for other drawbacks. Long cycling times were observed for the tallest genotypes (e.g., 'PKW'), but 'Yangambi $\mathrm{Km} 5$ ', which is intermediate in stature, unexpectedly took the longest to complete both crop cycles. It was also noteworthy that GCTCV and 'Formosana' test genotypes were generally slower in cycling when compared with the Cavendish reference genotype 'Williams'. The IBP test genotypes were similar in their overall agronomic performance when compared with the 'Gros Michel' reference genotype, but slight improvements in bunch size, number of fruits, and third hand metrics were observed for these selections, which agreed with the results of Bermudez et al. (2002). 'FHIA-21' showed comparable cycling times and exhibited improved number of fruit and size compared to those reported by GonzalezVelez (2014) for the Puerto Rican standard 'Maricongo' false-horn plantain (AAB). A potential drawback for 'FHIA-21' is that even with its disease resistance and favorable fruit attributes, the plants present a Frenchtype bunch that requires additional labor for de-handing. Differences in agronomic performance were also observed between the mother and first ratoon crops, but this was not 


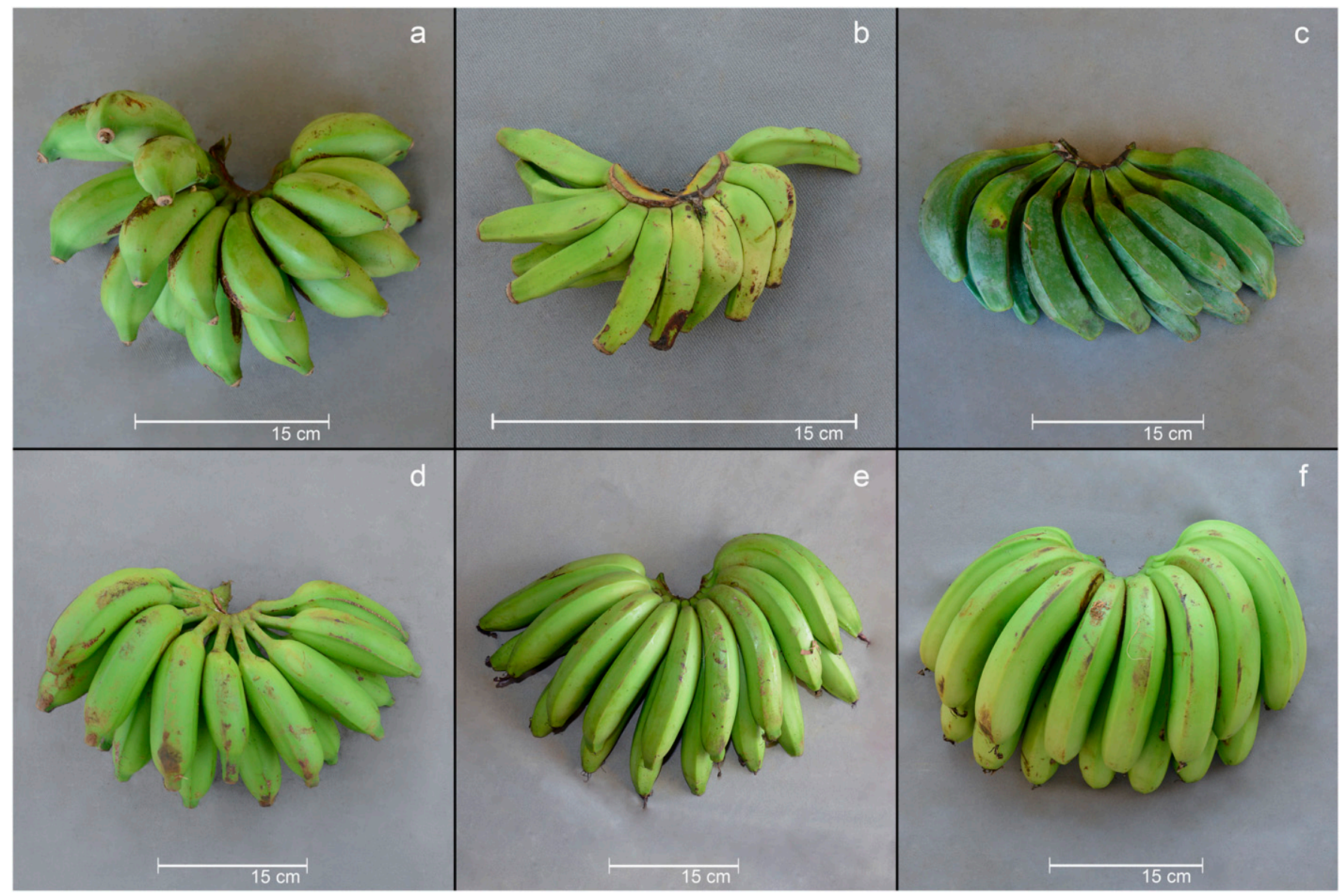

Fig. 3. Representative third hands and fruit for banana (Musa spp.) reference genotypes evaluated for black leaf streak (Pseudocercospora fijiensis Morelet) response and performance over two cropping cycles in Isabela, PR: (a) 'Yangambi'; (b) 'Calcutta 4'; (c) 'Pisang Klutuk Wulung'; (d) 'Pisang Ceylan'; (e) 'Gros Michel'; and (f) 'Williams'.

surprising because atypical behavior of field-evaluated tissue culture-derived plants has been observed before (Buah et al., 2000).

When compared with the Cavendish susceptible reference genotype 'Williams', the CGCTV selections generally did not do well. Only a few 'Formosana' plants and no 'GCTCV-119' survived through a second cycle of production; therefore, no data are presented for these two test genotypes. A "floating mat," where the rhizome seems to rise above the soil line, was apparent for 'CGCTC-119' and might have been partly to blame for the toppling over of plants in the ratoon crop. It is possible that these somaclonal selections might be variants (i.e., off-types) of the original selections, with consequent poor performance. Somaclonal variation, especially in tissue culture-propagated/ derived banana plants, has been frequently reported (Oh et al., 2007).

Although several of the test genotypes seemed to do well in field evaluations, it is ultimately consumer acceptance that determines the potential market. An informal sensory panel evaluated ripe fruit for appearance, texture, and flavor, with a few genotypes being favored. Both FHLORBAN genotypes ranked high in appearance, with 'Gros Michel' and derived genotypes preferred for flavor characteristics. A formal sensory evaluation is recommended to assess the acceptability of these introduced genotypes.

Based on subsequent surveys, following its initial detection, BLS has been clearly established in many Puerto Rican bananagrowing regions (Cortes et al., 2009; Irish et al., 2006, 2013). BLS and Sigatoka leaf spot have been reported to concomitantly occur in mixed infections. Reports also indicated that $P$. fijiensis replaces $P$. musae, especially at lower altitudes, and that detection of the two causal organisms based on symptoms is difficult (Carlier et al., 2002; Johanson et al., 2000; Mouliom-Pefoura et al., 1996). To clearly establish a causal agent in the current field evaluation, PCR assays were used (Arzanlou et al., 2007). Of the 20 isolates from the Isabela TARS research farm, only P. fijiensis amplified. These findings are similar to those reported by Irish et al. (2013), who indicated that only $P$. fijiensis was detected with a different species-specific PCR primer set (Johanson and Jeger, 1993) from a random survey of Pseudocercospora isolates. These results also agree with those of previous reports, indicating that $P$. fijiensis has become the predominant species. $P$. musae had been recovered in previous surveys of affected bananas on the TARS research farm conduct- ed in 2005. The township of Isabela happens to be a significant banana/plantain production area, and it is probably a good representative of what is happening elsewhere in lowland production regions on the island.

In conclusion, although no one test genotype met all the required attributes of a commercial banana substitute (e.g., diseaseresistant, productive, short cycling, acceptable fruit), several performed well. With their good yield, IBP selections might be important in production areas where FW race 1 has been reported in Puerto Rico (Garcia et al., 2018). In addition to its fusarium wilt resistance, Sun et al. (1996) indicated that the 'GCCTV-105' genotype has shown commercial potential. In the current study, although not significantly different from the Cavendish reference cultivar 'Williams', 'GCCTV105 ' exhibited increased agronomic production for bunch weight and numbers of hands and fruit. It is also important to note that CGCTV genotypes were selected for their disease tolerance to the TR4 strain of fusarium wilt and could still have economic potential if TR4 were to find its way into Cavendish production systems in Puerto Rico and the region.

The continued evaluation of diseaseresistant and agronomically improved banana germplasm, along with partners like 
Bioversity International and its International Musa Testing Program, might identify promising materials for production in Puerto Rico. Some of the currently evaluated test genotypes are reported to be tolerant and/or resistant to other organisms (e.g., Radopholus similis) and could be further assessed. New accessions of the off-types identified in this study and other improved selections could be brought in and evaluated. Introductions could possibly include other TRBRI genotypes with proven FW TR4 resistance and/or additional promising banana genotypes (e.g., 'PITA' hybrids from the International Institute for Tropical Agriculture) that are being developed. The introduced improved Musa spp. genotypes become part of the permanent TARS collection, and evaluation data associated with genotypes become available through the Germplasm Resources Information Network Global database.

\section{Literature Cited}

Abadie, C., Y. Chilin-Charles, C. Jenny, J. Huat, F. Salmon, L. Pignolet, J. Carlier, T . Lescot, F. Côte, and C. Jenny. 2009. New approaches to select cultivars of banana with durable resistance to Mycosphaerella leaf spot diseases. Acta Hort. 828:171-178.

Aktar, M.W., D. Sengupta, and A. Chowdhury. 2009. Impact of pesticides use in agriculture: Their benefits and hazards. Interdiscip. Toxicol. 2:1-12.

Anon. 1993. FHIA-21, un nuevo híbrido de plátano resistente a la Sigatoka negra. Informe Anual 1993. Fundación Hondureña de Investigación Agrícola (HND):2-3.

Arango Isaza, R.E., C. Diaz-Trujillo, B. Dhillon, A. Aerts, J. Carlier, C.F. Crane, T.V. de Jong, I. de Vries, R. Dietrich, A.D. Farmer, C.F. Fereira, S. Garcia, M. Guzman, R.C. Hamelin, E.A. Lindquist, R. Mehrabi, O. Quiros, J. Schmutz, H. Shapiro, E. Reynolds, G. Scalliet, M. Souza, Jr., I. Stergiopoulos, T.A.J. Van der Lee, P.J.G.M. De Wit, M.-F. Zapater, L.-H. Zwiers, I.V. Grigoriev, S.B. Goodwin, and G.H.J. Kema. 2016. Combating a global threat to a clonal crop: Banana black sigatoka pathogen Pseudocercospora fijiensis (synonym Mycosphaerella fijiensis) genomes reveal clues for disease control. PLoS Genet. 12(8):E1005876, doi: 10.1371/journal.pgen.1005876.

Arzanlou, M., E. Abeln, G. Kema, C. Waalwijk, J. Carlier, I. de Vries, M. Guzmán, and P.W. Crous. 2007. Molecular diagnostics for the Sigatoka disease complex of banana. Phytopathology 97:1112-1118.

Bakry, F., F. Carreel, C. Jenny, and J.P. Horry. 2009. Genetic improvement of banana, p. 3-50. In: S.M. Jain and P.M. Priyadarshan (eds.). Breeding plantation tree crops: Tropical species. Springer, New York, NY.

Bermudez, I., L. Herrera, P. Orellana Pérez, N. Veitia, C. Romero, J. Clavelo, L. Garcia, M. Acosta, and Y. Padron. 2002. Study of experimentally-induced variants of 'Manzano' (AAB) and 'Gros Michel' (AAA) bananas for their potential resistance to Fusarium wilt. Infomusa 11:7-8.

Boissenet, Y. 2002. Elaboration d'une méthode de développement de nouvelles variétés de bananes dessert d'exportation dans les Antilles françaises à partir de l'exemple de la variété IRFA 920 en Martinique. ENESAD, Dijon
(FRA). Mémoire Fin d'études: Techniques agricoles: Dijon, ENESAD: 2002.

Brown, A., R. Tumuhimbise, D. Amah, B. Uwimana, M. Nyine, H. Mduma, D. Talengera, D. Karamura, J. Kuriba, and R. Swennen. 2017. Bananas and Plantains (Musa spp.), p. 219240. In: Genetic improvement of tropical crops. Springer, Cham

Buah, J.N., Y. Kawamitsu, S. Yonemori, and S. Murayama. 2000. Field performance of in vitro-propagated and sucker-derived plants of banana (Musa spp.). Plant Prod. Sci. 3:124128.

Carlier, J., D. Waele, and J.V. Escalant. 2002. Global evaluation of Musa germplasm for resistance to Fusarium wilt, Mycosphaerella leaf spot diseases and nematodes. In: A. Vézina and C. Picq (eds.). INIBAP Technical Guidelines 6. The International Network for the Improvement of Banana and Plantain, Montpellier, France.

Cortes, M., M. Diaz, L. Gayol, A. Alvarado, E. Rosa-Marquez, and W. Almodovar. 2009. Distribucion de la Sigatoka negra (Mycosphaerella fijiensis) en Puerto Rico. J. Agr. Univ. P. R. 93:269-272.

Craenen, K. 1998. Technical manual on black sigatoka disease of banana and plantain. International Institute of Tropical Agriculture (IITA), Ibadan, Nigeria.

Dallot, S., P. Acuna, C. Rivera, P. Ramirez, R Cote, B.E.L. Lockhart, and M.L. Caruana. 2001. Evidence that the proliferation stage of micropropagation procedure is determinant in the expression of banana streak virus integrated into the genome of the FHIA 21 hybrid (Musa AAAB). Arch. Virol. 146:2179-2190.

Daniells, J.W., K.G. Pegg, C. Searle, M.K. Smith, T. Whiley, P. Langdon, N.J. Bryde, and T. O'Hare. 1995. Goldfinger in Australia: A banana variety with potential. Infomusa 4:5-6.

FAOSTAT. 2016. Food and Agriculture Organization of the United Nations. FAO, Rome, Italy. 12 Oct. 2018. <http://faostat3.fao.org/home/ $\mathrm{E}>$.

Garcia, R.O., L.I. Rivera-Vargas, R. Ploetz, J.C. Correll, and B.M. Irish. 2018. Characterization of Fusarium spp. isolates recovered from bananas (Musa spp.) affected by Fusarium wilt in Puerto Rico. Eur. J. Plant Pathol. 152:599-611.

Gauhl, F. 1994. Epidemiology and ecology of black sigatoka (Mycosphaerella fijiensis Morelet) on Plantain and Banana (Musa spp.) in Costa Rica, Central America. INIBAP, Montpellier, France.

Goenaga, R. and H. Irizarry. 2000. Yield and quality of banana irrigated with fractions of class A pan evaporation on an Oxisol. Agron. J. 92:1008-1012.

Goenaga, R. and H. Irizarry. 2006. Yield performance of two French-type plantain clones subjected to bunch pruning. J. Agr. Univ. P. R. 90:173-182.

Gonzalez, A. 2009. Comportamiento de cinco clones de plátano (Musa $\mathrm{AAB}$ ) sin manejo de la Sigatoka amarilla (Mycosphaerella musicola Leach). J. Agr. Univ. P. R. 93:1-2.

Gonzalez-Velez, A. 2014. Behavior of plantain clones Maricongo and FHIA 21 under the presence of black Sigatoka at the humid uplands of Puerto Rico. J. Agr. Univ. P. R. 98:2130.

Hwang, S.C. 2000. Recent developments on Fusarium $\mathrm{R}$ and $\mathrm{D}$ in Taiwan, p. 84-92. In: A.B. Molina and V.N. Roa (eds.). Proceedings of Ninth INIBAP-ASPNET Regional Advisory Committee Meeting, South China Agricultural University, Guangzhou (CHN), 1999/11/02-05.
Advancing banana and plantain $\mathrm{R}$ and $\mathrm{D}$ in Asia and the Pacific. INIBAP, Los Baños (PHL).

Hwang, S.C. and W.K. Ko. 1987. Somaclonal variation of bananas and screening for resistance to Fusarium wilt [Variation somaclonale des bananiers et évaluation de la résistance à la fusariose], p. 151-156. In: G.J. Persley and E.A.L. De Langhe (eds.). Proceedings of Banana and Plantain Breeding Strategies: Proceedings of an International Workshop, Cairns (AUS), 1986/10/13-17. Banana and plantain breeding strategies [Stratégies d'amélioration des bananiers et bananiers plantain]. ACIAR, Canberra, Australia. $<$ http://aciar.gov.au/files/node/2103/pr21_ pdf_74742.pdf $>$.

Hwang, S.C. and W.H. Ko. 1990. Selection of improved Cavendish banana mutants resistant to race 4 of Fusarium oxysporum f. sp. cubense. Acta Hort. 275:417-423.

Hwang, S.C. and W.H. Ko. 2004. Cavendish banana cultivars resistant to Fusarium wilt acquired through somaclonal variation in Taiwan. Plant Dis. 88:580-588.

Instituto de Estadísticas de Puerto Rico. 2016. Ingreso bruto agrícola. Departamento de Agricultura (DA), Oficina de Estadísticas Agrícolas. $<$ https://estadisticas.pr/>.

Irish, B.M., R. Goenaga, and R. Ploetz. 2006. Mycosphaerella fijiensis, causal agent of black Sigatoka of Musa spp. found in Puerto Rico and identified by polymerase chain reaction. Plant Dis. 90:684.

Irish, B.M., R. Goenaga, C. Rios, J. ChavarriaCarvajal, and R. Ploetz. 2013. Evaluation of banana hybrids for tolerance to black leaf streak (Mycosphaerella fijiensis Morelet) in Puerto Rico. Crop Prot. 54:229-238.

Irizarry-Alvarez, F. 2017. No hay plantanos en Puerto Rico. Primera Hora. <https://www. primerahora.com/>.

Jimenez, M., L. Van der Veken, H. Neirynck, H. Rodriguez, O. Ruiz, and R. Swennen. 2007. Organic banana production in Ecuador: Its implications on black Sigatoka development and plant-soil nutritional status. Renew. Agr. Food Syst. 22:297-306.

Johanson, A. and M.J. Jeger. 1993. Use of PCR for detection of Mycosphaerella fijiensis and $M$. musicola, the causal agents of Sigatoka leaf spots in banana and plantain. Mycol. Res. 97:670-674.

Johanson, A., W.K. Tushemereirwe, E.B. Karamura, K. Craenen, R. Ortiz, and D.R. Vuylsteke. 2000. Distribution of Sigatoka leaf spots in Uganda as determined by species-specific polymerase chain reaction (PCR). Acta Hort. 540:319-324

Jones, D.R. 2000a. Fungal diseases of the foliage, p. 37-141. In: D.R. Jones (ed.). Diseases of banana, Abacá and Enset. CABI, Wallingford (GBR).

Jones, D.R. 2000b. Banana breeding for disease resistance, p. 425-464. In: D.R. Jones (ed.). Diseases of banana, Abacá and Enset. CABI, Wallingford (GBR).

Khayat, E. and R. Ortiz. 2011. Genetics of important traits in Musa, p. 71-83. In: M. Pillay and A. Tenkouano (eds.). Banana Breeding. CRC Press, Boca Raton, FL.

Lee, S.Y., Y.U. Su, C.S. Chou, C.C. Liu, C.C. Chen, and C.P. Chao. 2011. Selection of a new somaclone cultivar 'Tai-Chiao No. 5' (AAA, Cavendish) with resistance to fusarium wilt of banana in Chinese Taipei, p. 391-397. In: I. Van den Bergh, M. Smith, R. Swennen, and C. Hermanto (eds.). Proceedings of International 
ISHS-ProMusa Symposium on Global Perspectives on Asian Challenges, Guangzhou, China, 14-18/09/2009. Acta Hort. 897. ISHS, Leuven, Belgium.

Meredith, D.S., J.S. Lawrence, and I.D. Firman. 1973. Ascospore release and dispersal on black leaf streak disease of bananas (Mycosphaerella fijiensis). Trans. Brit. Mycol. Soc. 60:547-554.

Molina, A.B., E.G. Fabregar, R.O. Soquita, and V.G.O. Sinohin. 2011. Comparison of host reaction to Fusarium oxysporum f. sp. cubense tropical race 4 and agronomic performance of somaclonal variant 'GCTCV-119' (AAA, Cavendish) and 'Grand Naine' (AAA, Cavendish) in commercial farms in the Philippines. In: I. Van den Bergh, M. Smith, R. Swennen, and C. Hermanto (eds.). Proceedings of International ISHS-ProMusa Symposium on Global Perspectives on Asian Challenges, Guangzhou, China, 14-18 Sept. 2009. ISHS, Leuven, Belgium. Acta Hort. 897:399-402.

Mouliom-Pefoura, A., A. Lassoudiere, J. Foko, and D.A. Fontem. 1996. Comparison of development of Mycosphaerella fijiensis and Mycosphaerella musicola on banana and plantain in the various ecological zones in Cameroon. Plant Dis. 80:950-954.

Oh, T.J., M.A. Cullis, K. Kunert, I. Engelborghs, R. Swennen, and C.A. Cullis. 2007. Genomic changes associated with somaclonal variation in banana (Musa spp.). Physiol. Plant. 129:766-774.

Ordonez, N., M.F. Seidl, C. Waalwijk, A. Drenth, A. Kilian, B.P.H.J. Thomma, R.C. Ploetz, and G.H.J. Kema. 2015. Worse comes to worst: Bananas and Panama disease-when plant and pathogen clones meet. PLoS Pathog. 11(11):E1005197, doi: 10.1371/journal.ppat. 1005197.

Orjeda, G. 1998. Evaluation of musa germplasm for resistance to sigatoka diseases and fusarium wilt. INIBAP Technical Guidelines 3. International Plant Genetic Resources Institute, Rome, Italy. International Network for the Improvement of Banana and Plantain, Montpellier, France; ACP-EU Technical Centre for Agricultural and Rural Cooperation, Wageningen, The Netherlands.

Orjeda, G., J. Escalant, and N. Moore. 1999. The international Musa Testing Programme (IMTP) phase II overview of final report and summary of results. Infomusa 8:3-10.
Ortiz, R. and R. Swennen. 2014. From crossbreeding to biotechnology-facilitated improvement of banana and plantain. Biotechnol. Adv. 32(1):158-169.

Perrier, X., E. De Langhe, M. Donohue, C. Lentfer, L. Vrydaghs, F. Bakry, F. Carreel, I. Hippolyte, J.-P. Horry, C. Jenny, V. Lebot, A.-M. Risterucci, K. Tomekpe, H. Doutrelepont, T. Ball, J. Manwaring, P. de Maret, and T. Denham. 2011. Multidisciplinary perspectives on banana (Musa spp.) domestication. Proc. Natl. Acad. Sci. USA 108:11311-11318.

Ploetz, R.C. and K.G. Pegg. 2000. Fungal diseases of the root, corm and pseudostem, p. 143-172. In: D.R. Jones (ed.). Diseases of banana, Abacá and Enset. CABI, Wallingford (GBR).

Puerto Rico Agricultural Experiment Station. 1995. Technological Package for the Production of Plantains and Bananas. Agric. Exp. Stn. Publ. 97. College of Agricultural Sciences, U. Puerto Rico, Mayaguez.

Price, N.S. 1994. Field trial evaluation of nematode susceptibility within Musa [Evaluation par essais en champ de la sensibilité aux nématodes chez le genre Musa] [Evaluación de la susceptibilidad a los nematodos en el género Musa en ensayos de campo.]. Fundam. Appl. Nematol. 17:391-396.

Quénéhervé, P., M. Godefroid, P. Topart, S. MarieLuce, F. Salmon, P. Marie, and C. Chabrier. 2012. Differential responses to plant-feeding nematodes among sibling cultivars of dessert bananas (Cavendish subgroup) and a synthetic hybrid. Crop Prot. 42:30-35.

Quénéhervé, P., F. Salmon, P. Topart, and J.P. Horry. 2009. Nematode resistance in bananas: Screening results on some new Mycosphaerella resistant banana hybrids. Euphytica 165:137143.

Ruas, M., V. Guignon, G. Sempere, J. Sardos, Y. Hueber, H. Duvergey, A. Andrieu, R. Chase, C. Jenny, T. Hazekamp, B. Irish, K. Jelali, J. Adeka, T. Ayala-Silva, C.P. Chao, J. Daniells, B. Dowiya, B. Effa effa, L. Gueco, L. Herradura, L. Ibobondji, E. Kempenaers, J. Kilangi, S. Muhangi, P. Ngo Xuan, J. Paofa, C. Pavis, D Thiemele, C. Tossou, J. Sandoval, A. Sutanto, G. Vangu Paka, G. Yi, I. Van den houwe, N. Roux, and M. Rouard. 2017. MGIS: Managing banana (Musa spp.) genetic resources information and high-throughput genotyping data.
Database (Oxford) 2017:bax046, doi:10.1093/ database/bax046.

Salmon, F., C. Bugaud, M. Chillet, M. Dorel, J.M. Risède, C. Jenny, and F.X. Cote. 2005. Development of a new promising banana hybrid: FLHORBAN 920, p. 274-283. In: M. Farant, G. Anais, H. Ozier Lafontaine, M.F. Zebus, J.L. Diman, and D. Hammouya (eds.). Alternatives to high input agriculture in the Caribbean: Towards the elaboration of innovation systems. CFCS, U.S. Virgin Islands.

Sardos, J., P. Christelova, J. Cizkova, J. Paofa, G.L. Sachter-Smith, S.B. Janssens, G. Rauka, M. Ruas, J.W. Daniells, J. Doležel, and N. Roux. 2018. Collection of new diversity of wild and cultivated bananas (Musa spp.) in the autonomous region of Bougainville, Papua New Guinea. Genet. Resources Crop Evol. 65(8):22672286.

Sun, P.M., S.C. Hwang, and W.H. Ko. 1996. GCTCV-105, a new Cavendish somaclone highly resistant to Fusarium wilt with commercial potential. Plant Protection Bul. (Taipei). 38:27-37.

Tang, C. and S.C. Hwang. 1994. Musa mutation breeding in Taiwan, p. 219-227. In: D.R. Jones (ed.). Proceedings of First Global Conference of the International Musa Testing Program, La Lima, Honduras, 1994/04/27-30. INIBAP, Montpellier (FRA).

USDA-NASS. 2012. United States Department of Agriculture, National Agricultural Statistics Service, Census for Agriculture. 12 Oct. 2018. $<$ https://www.nass.usda.gov/AgCensus/>.

U.S. Department of Agriculture. 2018. Natural Resources Conservation Service, Soil Climate Analysis Network. 5 Sept. 2018. <http://www.wcc. nrcs.usda.gov/scan/>.

Van den Bergh, I. and A. Vézina. 2018. "FLHORBAN 916", Musapedia, the banana knowledge compendium. 23 Nov. 2018. <http://www.promusa.org/FLHORBAN+916>.

Van den Bergh, I., A. Vézina, and J.-P. Horry. 2018. "FLHORBAN 920", Musapedia, the banana knowledge compendium. 23 Nov. 2018. $<$ http://www.promusa.org/FLHORBAN+920>.

Vuylsteke, D.R. 1989. Shoot-tip Culture for the Propagation, Conservation and Exchange of Musa Germplasm. International Institute of Tropical Agriculture, Ibadan, Nigeria. 
Supplemental Table 1. Mean SD and variance corresponding to disease response data presented in Table 3 for black leaf streak (Pseudocercospora fijiensis Morelet) of banana (Musa spp.) test and reference genotypes (bold) evaluated over two cropping cycles in Isabela, PR.

\begin{tabular}{|c|c|c|c|c|c|c|c|c|}
\hline \multirow[b]{3}{*}{ Accession } & \multicolumn{4}{|c|}{ First cycle (mother) } & \multicolumn{4}{|c|}{ Second cycle (first ratoon) } \\
\hline & \multicolumn{2}{|c|}{ No. of functional leaves } & \multicolumn{2}{|c|}{ DSI } & \multicolumn{2}{|c|}{ No. of functional leaves } & \multicolumn{2}{|c|}{ DSI } \\
\hline & Shoot & Harvest & Shoot & Harvest & Shoot & Harvest & Shoot & Harvest \\
\hline FLHORBAN 916 & $0.43 / 2.09$ & $0.52 / 2.99$ & $4.02 / 177.8$ & $0.38 / 1.6$ & $0.41 / 2.24$ & $0.6 / 4.75$ & $3.18 / 121.74$ & $0.25 / 0.81$ \\
\hline FLHORBAN 920 & $0.28 / 1.14$ & $0.66 / 6.26$ & $5.37 / 403.85$ & $0.29 / 1.18$ & $0.59 / 4.87$ & $0.54 / 4.09$ & $3.65 / 187.39$ & $0.62 / 5.49$ \\
\hline FHIA-21 & $0.39 / 1.87$ & $0.35 / 1.55$ & $1.05 / 13.37$ & $0.55 / 3.63$ & $0.46 / 2.62$ & $0.97 / 11.29$ & $1.71 / 29.56$ & $0.51 / 2.67$ \\
\hline IBP 12 & $0.3 / 1.32$ & $1.19 / 20.02$ & $2.03 / 53.75$ & $0.3 / 1.24$ & $0.33 / 1.12$ & $3.59 / 129.15$ & $6.04 / 511.08$ & $0.48 / 3.3$ \\
\hline IBP 5-B & $0.32 / 1.47$ & $0.95 / 12.81$ & $2.6 / 95.29$ & $0.27 / 1.05$ & $0.23 / 0.6$ & $1.73 / 33.3$ & $5.98 / 464.93$ & $0.36 / 1.73$ \\
\hline IBP 5-61 & $0.26 / 0.93$ & $0.9 / 10.64$ & $4.17 / 209.37$ & $0.23 / 0.61$ & $0.37 / 1.71$ & $1.8 / 39.21$ & $6.35 / 525.34$ & $0.51 / 3.47$ \\
\hline GCTCV-105 & $0.27 / 1.18$ & $1.69 / 45.71$ & $3.71 / 165.26$ & $0.27 / 0.87$ & $0.38 / 1.61$ & $2.98 / 98.24$ & $8.62 / 818.99$ & $0.09 / 0.09$ \\
\hline GCTCV-119 & $0.27 / 1.17$ & $1.39 / 29.15$ & $3.7 / 206.07$ & $0.47 / 3.4$ & & & & \\
\hline Formosana & $0.37 / 1.14$ & $2.63 / 55.55$ & $0.83 / 4.18$ & $0.21 / 0.26$ & & & & \\
\hline Yangambi Km5 & $0.3 / 1.46$ & $2 / 64.43$ & $5.43 / 471.97$ & $0.28 / 1.33$ & $0.74 / 5.02$ & $3.86 / 134.5$ & 10.41/977.04 & $0.86 / 6.77$ \\
\hline Calcutta 4 & $0.22 / 0.68$ & $0.4 / 2.28$ & $\mathbf{0} / \mathbf{0}$ & $0.47 / 3.14$ & $0.59 / 5.66$ & $\mathbf{0} / \mathbf{0}$ & $0.97 / 11.3$ & $0.44 / 2.38$ \\
\hline P. Klutuk Wulung & $0.72 / 4.77$ & $0.39 / 1.42$ & $2.68 / 57.49$ & $0.55 / 2.5$ & $0.66 / 4$ & $1.84 / 30.73$ & $13.39 / 1076.24$ & $2.15 / 27.76$ \\
\hline Pisang Ceylan & $0.45 / 2.44$ & $1.47 / 25.93$ & $3.51 / 197.87$ & $0.42 / 2.91$ & $0.55 / 4.02$ & $1.37 / 24.51$ & 1.71/38.08 & $0.48 / 3.08$ \\
\hline Gros Michel & $0.27 / 1.05$ & $1.92 / 51.71$ & $4.88 / 382.18$ & $0.57 / 5.26$ & $0.34 / 1.64$ & $0.82 / 9.61$ & 7/637.69 & $0.44 / 2.56$ \\
\hline Williams & $0.57 / 4.3$ & $2.25 / 66.2$ & $3.43 / 153.19$ & $0.33 / 1.47$ & $0.26 / 1.01$ & $2.76 / 106.68$ & $9.34 / 1136.03$ & $\mathbf{0} / \mathbf{0}$ \\
\hline
\end{tabular}

${ }_{\mathrm{sD} / \text { variance. }}$

Supplemental Table 2. Mean SD and variance corresponding to agronomic performance data presented in Table 4 for banana (Musa spp.) test and reference genotypes (bold) evaluated for black leaf streak (Pseudocercospora fijiensis Morelet) response and performance over two cropping cycles in Isabela, PR.

\begin{tabular}{|c|c|c|c|c|c|c|c|c|}
\hline \multirow[b]{3}{*}{ Accession } & \multicolumn{4}{|c|}{ First cycle (mother) } & \multicolumn{4}{|c|}{ Second cycle (first ratoon) } \\
\hline & \multicolumn{2}{|c|}{ Days to } & \multicolumn{2}{|c|}{ Plant } & \multicolumn{2}{|c|}{ Days to } & \multicolumn{2}{|c|}{ Plant } \\
\hline & Shoot & Harvest & Ht (m) & Circ. $(\mathrm{cm})$ & Shoot & Harvest & Ht (m) & Circ. $(\mathrm{cm})$ \\
\hline FLHORBAN 916 & $9.64 / 1,023.89^{z}$ & $8.95 / 882.21$ & $0.03 / 0.01$ & $0.9 / 8.96$ & $18.93 / 4,659.83$ & $16.66 / 3,332.74$ & $0.08 / 0.09$ & $1.68 / 36.72$ \\
\hline FLHORBAN 920 & $2.40 / 80.86$ & $8.70 / 1,061.51$ & $0.02 / 00$ & $0.36 / 1.89$ & $14.11 / 2,790.61$ & $20.08 / 5,645.17$ & $0.05 / 0.04$ & $0.71 / 6.57$ \\
\hline FHIA-21 & $20.55 / 5,069.21$ & $20.61 / 5,097.79$ & $0.05 / 0.03$ & $1.55 / 29.09$ & $31.87 / 12,194.94$ & $26.43 / 6,288.46$ & $0.10 / 0.12$ & $3.44 / 142.65$ \\
\hline IBP 12 & $3.09 / 134.20$ & $2.07 / 60.38$ & $0.02 / 0.01$ & $0.67 / 6.31$ & $17.32 / 3,000.55$ & $16.87 / 2,848.21$ & $0.08 / 0.07$ & $1.64 / 27.04$ \\
\hline IBP 5-B & $3.87 / 195.67$ & $2.43 / 65.17$ & $0.03 / 0.01$ & $0.9 / 10.73$ & $22.25 / 5,942.90$ & $11.71 / 1,509.56$ & $0.06 / 0.05$ & $2.06 / 51.28$ \\
\hline IBP 5-61 & $6.12 / 526.07$ & $4.52 / 287.27$ & $0.05 / 0.04$ & $1.18 / 19.54$ & $17.04 / 3,195.05$ & $17.25 / 3,276.27$ & $0.05 / 0.02$ & $1.77 / 31.67$ \\
\hline GCTCV-105 & $3.76 / 227.10$ & $4.01 / 209.53$ & $0.05 / 0.03$ & $0.76 / 9.33$ & $15.70 / 2,711.70$ & $12.54 / 1,730.36$ & $0.05 / 0.03$ & $0.89 / 8.80$ \\
\hline GCTCV-119 & $4.36 / 285.97$ & $5.49 / 423.13$ & $0.04 / 0.03$ & $0.61 / 5.64$ & & & & \\
\hline Formosana & $7.63 / 465.84$ & $10.47 / 877.36$ & $0.03 / 00$ & $0.72 / 4.22$ & & & & \\
\hline Yangambi Km5 & $5.88 / 553.26$ & 4.57/334.97 & $0.03 / 0.02$ & $0.64 / 6.61$ & $6.25 / 351.90$ & 8.31/553.14 & $0.07 / 0.05$ & $1.04 / 9.91$ \\
\hline Calcutta 4 & $1.57 / 34.58$ & 2.63/97.34 & $0.02 / 0.01$ & $0.72 / 7.42$ & $10.70 / 1,831.94$ & $13.52 / 2,743.31$ & $0.05 / 0.04$ & $1.21 / 23.71$ \\
\hline P. Klutuk Wulung & $25.79 / 5,324.22$ & $20.07 / 3,223.13$ & $0.08 / 0.06$ & $1.5 / 20.40$ & $23.89 / 5,140.03$ & 13.24/1,051.86 & $0.07 / 0.05$ & 2.19/43.31 \\
\hline Pisang Ceylan & $31.32 / 11,778.40$ & $34.51 / 14,298.29$ & $0.06 / 0.04$ & $1.23 / 18.29$ & $31.84 / 13,185.28$ & $29.10 / 10,167.54$ & $0.09 / 0.11$ & $2.07 / 55.99$ \\
\hline Gros Michel & $5.52 / 427.24$ & $5.93 / 387.74$ & $0.08 / 0.09$ & $0.53 / 3.97$ & 9.95/1,387.46 & $6.67 / 490.71$ & $0.07 / 0.08$ & $1.15 / 18.66$ \\
\hline Williams & 4.27/237.05 & $3.62 / 157.96$ & $0.07 / 0.07$ & $0.65 / 5.52$ & $29.85 / 12,480.59$ & $37.39 / 16,780.75$ & $0.13 / 0.24$ & $1.81 / 46.21$ \\
\hline
\end{tabular}

${ }_{\mathrm{zD}} /$ variance 
Supplemental Table 3. Mean SD and variance corresponding to yield data presented in Table 5 for first cycle (mother) banana (Musa spp.) test and reference genotypes (bold) evaluated for black leaf streak (Pseudocercospora fijiensis Morelet) response and performance in Isabela, PR.

\begin{tabular}{|c|c|c|c|c|c|c|}
\hline \multirow[b]{2}{*}{ Accession } & \multicolumn{3}{|c|}{ Bunch } & \multicolumn{3}{|c|}{ Third hand } \\
\hline & Wt (kg) & Hands (no.) & Fruits (no.) & Wt (kg) & Length $(\mathrm{cm})$ & Width $(\mathrm{cm})$ \\
\hline FLHORBAN 916 & $0.76 / 5.77^{z}$ & $0.27 / 0.85$ & $6.37 / 447.4$ & $0.09 / 0.09$ & $0.5 / 2.84$ & $0.04 / 0.02$ \\
\hline FLHORBAN 920 & $0.97 / 11.48$ & $0.2 / 0.56$ & $4.65 / 281.93$ & $0.35 / 1.54$ & $0.46 / 2.62$ & $0.03 / 0.01$ \\
\hline FHIA-21 & $1.28 / 19.69$ & $0 / 0$ & $2.95 / 104.99$ & $0.37 / 1.69$ & $0.53 / 3.4$ & $0.08 / 0.07$ \\
\hline IBP 12 & $1.01 / 13.32$ & $0.16 / 0.37$ & $2.82 / 111.82$ & $0.2 / 0.46$ & $0.49 / 2.93$ & $0.06 / 0.05$ \\
\hline IBP 5-B & $1.15 / 16$ & $0.14 / 0.26$ & $3.45 / 143.29$ & $0.17 / 0.35$ & $0.28 / 0.98$ & $0.07 / 0.06$ \\
\hline IBP 5-61 & $1.36 / 25.96$ & $0.21 / 0.64$ & $4.68 / 306.83$ & $0.1 / 0.14$ & $0.4 / 2.12$ & $0.05 / 0.04$ \\
\hline GCTCV-105 & $1.7 / 34.8$ & $0.22 / 0.6$ & $5.54 / 369.17$ & $0.19 / 0.46$ & $0.29 / 1.06$ & $0.08 / 0.09$ \\
\hline GCTCV-119 & $0.82 / 9.59$ & $0.35 / 1.75$ & $8.29 / 962.86$ & $0.1 / 0.17$ & $0.29 / 1.34$ & $0.06 / 0.06$ \\
\hline Formosana & $0.91 / 5.83$ & $0.26 / 0.55$ & $4.01 / 129.12$ & $0.11 / 0.1$ & $0.36 / 1.06$ & $0.05 / 0.02$ \\
\hline Yangambi Km5 & $0.19 / 0.55$ & $0.17 / 0.45$ & $5.18 / 402.57$ & $0.05 / 0.05$ & $0.16 / 0.42$ & $0.04 / 0.03$ \\
\hline Calcutta 4 & $0.1 / 0.13$ & $0.35 / 1.47$ & $5.95 / 460.93$ & $0.03 / 0.01$ & $0.32 / 1.4$ & $0.04 / 0.03$ \\
\hline P. Klutuk Wulung & $0.84 / 4.99$ & $0.4 / 1.14$ & $6.54 / 300.28$ & $0.27 / 0.67$ & $1.17 / 12.36$ & $0.31 / 0.88$ \\
\hline Pisang Ceylan & $1.35 / 29.28$ & $0.27 / 1.2$ & $6.08 / 592.12$ & $0.11 / 0.17$ & $0.29 / 1.18$ & $0.07 / 0.08$ \\
\hline Gros Michel & $1.43 / 32.79$ & $0.3 / 1.46$ & $6.79 / 738.06$ & $0.24 / 0.9$ & $0.46 / 3.26$ & $0.08 / 0.1$ \\
\hline Williams & $1.51 / 29.92$ & $0.3 / 1.24$ & $8.94 / 1,041.24$ & $0.26 / 0.79$ & $1.08 / 12.95$ & $0.11 / 0.14$ \\
\hline
\end{tabular}

$\mathrm{z}_{\mathrm{SD} / \text { variance. }}$

Supplemental Table 4. Mean SD and variance corresponding to yield data presented in Table 6 for second cycle (first ratoon) banana (Musa spp.) test and reference genotypes (bold) evaluated for black leaf streak (Pseudocercospora fijiensis Morelet) response and performance in Isabela, PR.

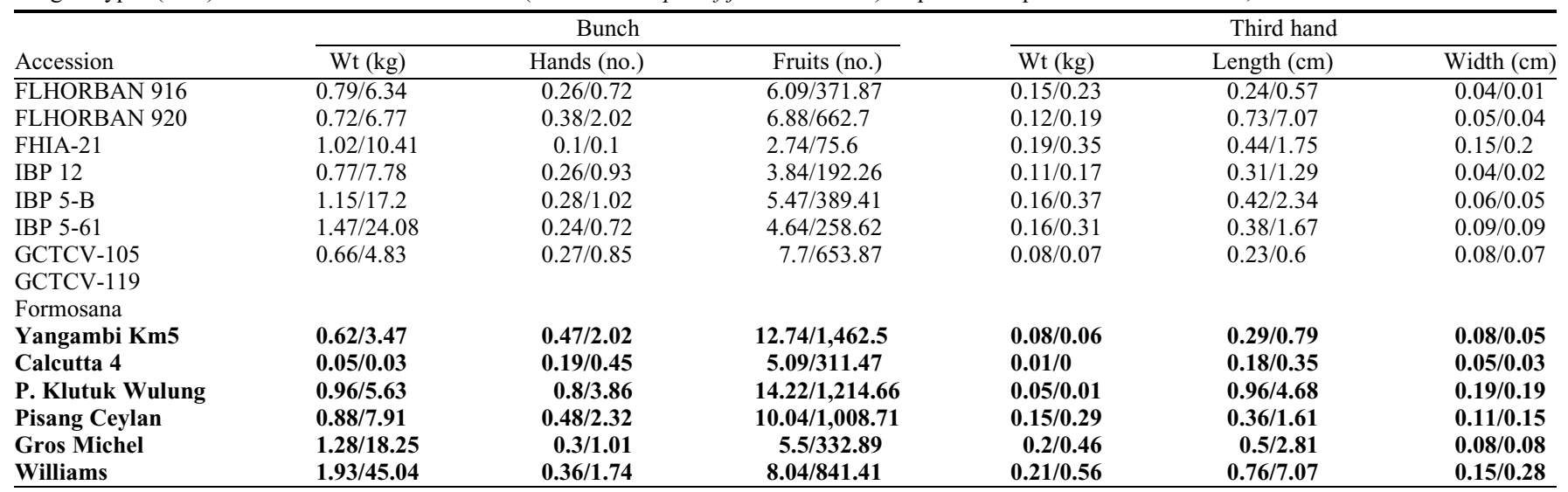

${ }_{\mathrm{SD} / \text { variance. }}$ 